2015

\title{
God and Guns: The Free Exercise of Religion Problems of Regulating Guns in Churches and Other Houses of Worship
}

John M.A. DiPippa

University of Arkansas at Little Rock William H. Bowen School of Law, jmdipippa@ualr.edu

Follow this and additional works at: http://lawrepository.ualr.edu/faculty_scholarship

Part of the Constitutional Law Commons, and the Religion Law Commons

\section{Recommended Citation}

John M.A. DiPippa, God and Guns: The Free Exercise of Religion Problems of Regulating Guns in Churches and Other Houses of Worship, 98 Marq. L. Rev. 1103 (2015).

This Article is brought to you for free and open access by Bowen Law Repository: Scholarship \& Archives. It has been accepted for inclusion in Faculty Scholarship by an authorized administrator of Bowen Law Repository: Scholarship \& Archives. For more information, please contact mmserfass@ualr.edu. 


\title{
GOD AND GUNS: THE FREE EXERCISE OF RELIGION PROBLEMS OF REGULATING GUNS IN CHURCHES AND OTHER HOUSES OF WORSHIP
}

\author{
JOHN M.A. DIPIPPA*
}

This Article demonstrates that the cases raising religious liberty challenges to state regulation of weapons in houses of worship reveal the persistent problems plaguing religious liberty cases. First, these cases illustrate the difficulties non-mainstream religious claims face. Courts may not understand the religious nature of the claim or they may devalue claims that do not seem "normal" or "reasonable." This is compounded by how few religious liberty claimants, especially non-mainstream religions, win their cases. Second, the cases are part of the larger debate about how easy it should be to get judicially imposed religious exemptions from general and neutral laws. Uncritically granting exemptions could undermine the statutory scheme and the rule of law. Too stingy an approach and religious freedom becomes an empty promise. Third, the cases show the problems with a neutral approach. Neutrality is often held out as the appropriate touchstone for religious liberty analysis. Finding a neutral standpoint, however, is difficult, if not impossible, especially when dealing with religion. This difficulty forces courts to find "neutrality" by silently relying on their background assumptions about religion, which only exacerbates the problems of non-mainstream claimants. These three difficulties have relevance to the current litigation concerning the Patient Protection and Affordable Care Act.

This Article concludes that these persistent problems flow from the ambiguity about religious liberty's purpose. Adopting one or another perspective dictates the paths that courts take in religious liberty cases.

* Dean Emeritus and Distinguished Professor of Law and Public Policy, University of Arkansas at Little Rock William H. Bowen School of Law. A summer research grant supported the work on this Article. Thanks to Leslie Copeland and Joyce Olajumoke Ajayi who provided expert research assistance and advice when I needed it the most and to Terri Beiner, Associate Dean for Faculty Development, who gently but persistently encouraged me to return to my scholarship after years of mind numbing work as a law school administrator. Thanks also to my colleagues who attended a faculty development lunch where they heard a much rougher version of this piece. 
I. INTRODUCTION

II. BASIC GUN CONTROL MEASURES AND HOUSES

OF WORSHIP.

III. THE Two CASES RaIsing Issues of RELIGIOUS

LIBERTY AND GUNS

IV. THE RELEVANCE OF SIKHS AND KIRPANS

V. IS THERE A RELIGIOUS DUTY OF SELF DEFENSE?

VI. RELIGIOUS LIBERTY ISSUES IN CATEGORICAL AND OPT-OUT JURISDICTIONS

VII. THREE PERSISTENT RELIGIOUS LIBERTY PROBLEMS.

A. The Non-Mainstream Religion Problem................................1128

B. The Exemption Problem

C. The Neutrality Problem

VIII.CONCLUSION: WHAT'S FREE EXERCISE FOR?.

\section{INTRODUCTION}

In 2013, the Arkansas General Assembly allowed people to take guns into places of worship. ${ }^{1}$ Representatives of religious congregations offered differing testimony on the need for the bill. ${ }^{2}$ Some legislators were concerned that a categorical prohibition violated religious liberty. ${ }^{3}$

1. Act of Feb. 11, 2013, Act 67, $\S 1,2013$ Ark. Acts 273, 274 (codified as amended at ARK. CODE ANN. § 5-73-306(16) (Supp. 2013)). Prior law categorically exempted churches. Id. \$5-73-306(17) (1997). The new statute continues this categorical exemption but "does not preclude a church or other place of worship from determining who may carry a concealed handgun into the church or other place of worship." Id. § 5-73-306(16)(B) (Supp. 2013). This issue came up in the 2011 legislative session during which I was asked for my opinion on the free exercise implications of the former categorical exemption for churches. See Lee Hogan, Beebe Signs Guns in Church Bill into Law, ARK. ONLINE (Feb. 11, 2013, 1:26 PM), http://ww w.arkansasonline.com/news/2013/feb/11/gov-beebe-signs-guns-church-bill-law/, archived at $\mathrm{htt}$ $\mathrm{p}: / /$ perma.cc/B2MW-7BH4.

2. See Sean Beherec, Michael R. Wickline \& Sarah D. Wire, Church Leaders Give Views on Guns in Sanctuaries, ARK. DEMOCRAT GAZETTE, Feb. 1, 2013, at 8A.

3. See Letter from Dustin McDaniel, Attorney Gen., to Beverly Pyle, Ark. State Legislature Representative (Sept. 29, 2009). Representative Pyle, the requestor, also asked for my opinion. See letter on file with author. The legislation included an "Emergency Clause" declaring that

personal security is increasingly important; that the Second Amendment of the Constitution of the United States ensures a person's right to bear arms; and that this act is immediately necessary because a person should be allowed to carry a firearm in a church that permits the carrying of a firearm for personal security.

Act $67,82,2013$ Ark. Acts at 274 . So-called "emergency clauses" are routinely added to legislation to allow laws to go into effect immediately. Opponents of the change offered 
This argument was similar to the one made by Georgia churches that sued the state over its categorical prohibition on guns in churches. ${ }^{4}$ On the other hand, Minnesota churches sued the state when that state changed the law to allow guns in houses of worship. ${ }^{5}$

This correlation of guns and religion raises a number of interesting, non-trivial questions about the application of First Amendment law and the nature of religious liberty. This Article will explore some of those questions. $^{6}$

\section{BASIC GUN CONTROL MEASURES AND HOUSES OF WORSHIP}

Gun control measures revolve around two basic issues: who should be allowed to carry a gun and where those guns should be allowed to be carried. ${ }^{7}$ The first focuses on how easy it should be to carry guns and who should be allowed to carry them. ${ }^{8}$ The second focuses on where those guns should be allowed. ${ }^{9}$

explicitly religious arguments for continuing the ban during a previous attempt to amend the bill. See Charlie Frago \& Michael R. Wickline, House Passes Gun-in-Church Bill, ARK. DEMOCRAT GAZETTE, Feb. 12, 2009, at A10.

4. See GeorgiaCarry.org, Inc. v. Georgia, 687 F.3d 1244, 1255 (11th Cir. 2012), cert. denied, 133 S. Ct. 856 (2013).

5. See Edina Cmty. Lutheran Church v. State, 745 N.W.2d 194, 198 (Minn. Ct. App. 2008).

6. The Second Amendment implications of categorical gun bans in sensitive places are beyond the scope of this Article. There is an extensive and growing body of scholarship on Second Amendment issues. See, e.g., Eugene Volokh, Implementing the Right to Keep and Bear Arms for Self-Defense: An Analytical Framework and a Research Agenda, 56 UCLA L. REV. 1443 (2009).

7. This follows Heller's reminder that Second Amendment rights are not absolute and its brief list of permissible categories of regulations. District of Columbia v. Heller, 554 U.S. $570,626-27$ (2008) (" $[N]$ othing in our opinion should be taken to cast doubt on longstanding prohibitions on the possession of firearms by felons and the mentally ill, or laws forbidding the carrying of firearms in sensitive places such as schools and government buildings...."); see also Saul Cornell, The Right to Carry Firearms Outside of the Home: Separating Historical Myths from Historical Realities, 39 FORDHAM URB. L.J. 1695, 1719 n.132 (2012) (citing nineteenth-century statutes banning guns in sensitive places).

8. Some states allow gun holders to carry their guns openly. Open Carry, OPENCARRY.ORG, http://www.opencarry.org/?page_id=103 (last visited Mar. 15, 2015), archived at http://perma.cc/PX9P-FFG8 (labeling Alaska, Arkansas, Arizona, Idaho, Kansas, Kentucky, Mississippi, Montana, Nevada, New Mexico, North Carolina, South Dakota, Vermont, Virginia and Wyoming as "Gold Star" open carry states, and labeling Florida, Illinois, New York, South Carolina, Texas, and Washington D.C. as "Non Permissive" opencarry states). Other states require gun owners to conceal their guns when in public. Id.; see also Ginny Fahs, Illinois Is 50th State to Legalize Carrying Concealed Weapons, NPR (July 10, 2013, 2:10 PM), http://www.npr.org/blogs/the-two-way/2013/07/10/200789406/Illinois-is-50th-st ate-to-legalize-carrying-concealed-weapons, archived at http://perma.cc/V6NJ-8ZKS 
One rationale is that although carrying weapons in public may be helpful for individual self-defense, that justification breaks down in large public gatherings. ${ }^{10}$ Most people will be unarmed and crowded into a confined space. Even one person with a gun may cause considerable injury before being stopped. Moreover, an exchange of gunfire between the "good guys" and the "bad guys" may be just as dangerous as a lone gunman. ${ }^{11}$ Another rationale is that some places are incompatible with weapons. Schools, courthouses, government buildings, and legislative chambers are places where either vulnerable populations are housed (like schools) or where public business is conducted. The use or threat of force is incompatible with this property's function. Finally, some "sensitive places" provide security by screening people who enter, thus obviating the need for an individual to be armed for self-defense. ${ }^{12}$ Houses of worship share some but not all of the characteristics of each of these categories. ${ }^{13}$

(reporting that all fifty states now have provisions for concealed carrying of weapons). Some states require officials to issue permits if applicants meet certain threshold requirements. See Steven W. Kranz, Comment, A Survey of State Conceal and Carry Statutes: Can Small Changes Help Reduce the Controversy?, 29 HAMLINE L. REV. 637, 670-708 (2006) (listing 35 states in the Appendix as "shall-issue" states). Embedded into these processes is the question of who, if anyone, should not be allowed to carry a gun. See, e.g., 18 U.S.C. $\$ 922$ (d) (2012) (prohibiting the sale or disposition of firearms to felons, fugitives, illegal aliens, and domestic violence offenders, among others); id. $\$ 922(\mathrm{x})(2)$ (prohibiting juveniles from possessing a handgun or handgun ammunition).

9. Volokh, supra note 6, at 1515 ("Many laws prohibit most people from possessing guns in certain places, such as on all public streets, in bars, in parks, and in public housing projects.").

10. See, e.g., Nordyke v. King, 563 F.3d 439, 459-60 (9th Cir. 2009), vacated on other grounds, 611 F.3d 1015 (9th Cir. 2010) (upholding ban on possession of firearms in "open air" places "because possessing firearms in such places risks harm to great numbers of defenseless people (e.g., children)").

11. See Nordyke, 563 F.3d at 459 (ruling against open carry and, for that matter, carry laws). The Supreme Court recently declined to hear three cases challenging gun laws, giving rise to the inference that states may proscribe gun possession in certain places. Lawrence Hurley, Supreme Court Declines Challenges to Gun Laws, REUTERS (Feb. 24, 2014, 10:00 AM), http://www.reuters.com/article/2014/02/24/us-usa-court-guns-idUSBREA1N1282014022 4, archived at http://perma.cc/KD3A-9TJM.

12. Brian C. Whitman, In Defense of Self-Defense: Heller's Second Amendment in Sensitive Places, 81 MISS. L.J. 1987, 1989-90 (2012).

13. Id. at 2007-08 (calling gun bans in houses of worship an "obvious violation" of the Second Amendment). Colleges and universities are often included in these lists, too. Id. at 2006-07. The constitutionality of gun bans on campus is fiercely contested. Compare Joan $\mathrm{H}$. Miller, Comment, The Second Amendment Goes to College, 35 SEATTLE U. L. REV. 235 (2011) (arguing that broad gun bans are constitutional), with Brian Miller, Legal Experts: Campus Gun Bans Flawed, Unconstitutional, COLLEGE FIX (Jan. 14, 2013), http://www.thecol 
Other states permit holders to carry guns anywhere but allow property owners to ban weapons on their property by posting notices or using other methods to notify permit holders. ${ }^{14}$ In opt-out jurisdictions, permit holders can carry guns into houses of worship unless the organization posts notices declaring its property a gun-free zone. ${ }^{15}$ Churches and other houses of worship have argued that requiring them to post opt-out notices violated their religious beliefs in peace and in offering worshipers a safe and inclusive sanctuary. ${ }^{16}$ In the categorical jurisdictions, churches have argued that the total ban violates their religious freedom. ${ }^{17}$ They believe that it is "right and just" for their members to attend services armed and the state cannot interfere with this belief and action. ${ }^{18}$

These claims raise questions about the nature of religious freedom in today's world as well as the adequacy of current First Amendment law. ${ }^{19}$ One might be suspicious of claims that "God requires us to bring our weapons to church," but claiming a divine command to be armed is not unprecedented. ${ }^{20}$ Sikhs have long made this exact claim. ${ }^{21}$ Modern-day

legefix.com/post/12393/, archived at http:/perma.cc/8UV6-8ZXT (reporting that some professors suggest that "[s]ome campus firearms regulations" may violate student and employee rights under the Constitution). See generally David B. Kopel, Pretend "Gun-Free" School Zones: A Deadly Legal Fiction, 42 CoNN. L. REV. 515 (2009); Brian J. Siebel, The Case Against Guns on Campus, 18 GeO. MASON U. C.R. L.J. 319 (2008); Lewis M. Wasserman, Gun Control on College and University Campuses in the Wake of District of Columbia v. Heller and McDonald v. City of Chicago, 19 VA. J. SOC. POL'Y \& L. 1, 55 (2011) (stating that "thoughtfully adopt[ed]" gun bans based on scientific research are consistent with Heller, and McDonald restrictions are probably constitutional).

14. ARK. CODE ANN. §\$ 5-73-306(19)(A)(i) (1997 \& Supp. 2013); Ky. REV. STAT. ANN. $\S 237.110(17)$ (LexisNexis 2012 \& Supp. 2013); MINN. STAT. ANN. \$ 624.714(17)(a) (West 2009 \& Supp. 2015); MISS. CODE ANN. § 45-9-101(13) (2011 \& Supp. 2012); MO. ANN. STAT. \$ 571.107(1)(15) (West 2011 \& Supp. 2014); N.M. STAT. ANN. § 29-19-12(C) (LexisNexis 2013); id. § 30-14-6(A)-(B) (LexisNexis 2004); N.C. GEN. STAT. § 14-415.11(c)(8) (2011); OHIO REV. CODE ANN. \& 2923.12.6(C)(3) (LexisNexis 2010 \& Supp. 2014); OKLA. STAT. ANN. tit. 21, § 1290.22(C) (West Supp. 2014); S.C. CODE ANN. §23-1-220(2) (2007); TENN. CODE ANN. \$ 39-17-1359(a)-(b) (2010); TEX. PENAL CODE ANN. § 30.06(b) (West 2011). I will refer to these states, collectively, as "opt-out jurisdictions."

15. See Edina Cmty. Lutheran Church v. Minnesota, 745 N.W.2d 194, 202 (Minn. Ct. App. 2008).

16. Id. at $199-202$.

17. See GeorgiaCarry.org, Inc. v. Georgia, 687 F.3d 1244, 1255 (11th Cir. 2012).

18. See id. at 1249 n.8.

19. See Stephen M. Feldman, Religious Minorities and the First Amendment: The History, the Doctrine, and the Future, 6 U. PA. J. CONST. L. 222 (2003) [hereinafter Feldman, Religious Minorities].

20. See David B. Kopel, Evolving Christian Attitudes Towards Personal and National Self-Defense, 45 CONN. L. REv. 1709 (2013) [hereinafter Kopel, Evolving Attitudes]; David B. 
Christians, on the other hand, must infer such a duty. ${ }^{22}$ The result could be a corruption of religion with the latest political cause. ${ }^{23}$ At the same time, this very suspicion should make us wary. It is an enduring problem of free exercise law that we will tolerate the religious claims that seem most reasonable because they seem "normal." 24

Current First Amendment law cannot coherently address these different situations. In the categorical jurisdictions, the claims will founder on whether or not the law actually burdens a religious belief because the religious claim collapses into the secular preference to be armed. ${ }^{25}$ Yet the categorical exclusion of places of worship singles them out for exceptional treatment and includes them with other areas that may have little in common with places of worship. ${ }^{26}$ In the opt-out jurisdictions, the claim will founder because, although it may be easier for a court to see a religious burden, the laws will be neutral and generally applicable. ${ }^{27}$ They do not single out religion. Rather, they allow churches to opt out by following exactly the same procedures as any other property owner. ${ }^{28}$ Yet this seems to demean the religious nature of the claim - providing sanctuary-and reduces it, once again, to a matter of personal preference.

In both instances, the religious nature of the claim confounds the analysis. Courts devalue the religious nature of the claim when they privilege mainstream or "normal" religious claims..$^{29}$ At the same time, religious adherents must tame or sanitize their claim for it to be

Kopel, The Religious Roots of the American Revolution and the Right to Keep and Bear Arms, 17 J. FIREARMS \& PUB. POL'Y 167 (2005) [hereinafter Kopel, Religious Roots].

21. See Michael Baker, Security and the Sacred: Examining Canada's Legal Response to the Clash of Public Safety and Religious Freedom, 13 TOURO INT'L L. REv. 1, 15-16 (2010).

22. See Kopel, -Otudes, supra note 20.

23. See id.

24. See infra Part VII.A.

25. See infra text accompanying notes 74-81; see also Blake Farmer, Kentucky Southern Baptists Draw Crowds With Gun Giveaways, NPR (Mar. 10, 2014, 3:02 AM), http://www.npr.o rg/2014/03/10/287311237/Kentucky-southern-baptists-draw-crowds-with-gun-giveaways?utm_ medium=Email\&utm_source $=$ share\&utm_campaign=storyshare, archived at http://perma.cc/6 KAV-28PZ.

26. Examples include legislative buildings or public parks. See, e.g., GeorgiaCarry.org, Inc. v. Georgia, 687 F.3d 1244, 1255 (11th Cir. 2012)

27. See Emp't Div. v. Smith, 494 U.S. 872 (1990) (stating that laws must be neutral and generally applicable).

28. See supra note 14.

29. See infra Part VII.A. 
understood and accepted by courts. ${ }^{30}$ This has relevance for other free exercise claims. Indeed, it is one of the most problematic aspects of free exercise law. ${ }^{31}$ If courts too easily grant religious exemptions, the rule of law is undermined. ${ }^{32}$ On the other hand, unless courts remain open to "unusual" religious claims, free exercise law is a tautology: the only religious practices we protect are the ones we already practice.

\section{THE TWo CASES RAISING ISSUES OF RELIGIOUS LIBERTY AND GUNS}

In 2005, the Minnesota legislature passed the Minnesota Citizens' Personal Protection Act. ${ }^{33}$ The act made Minnesota a "shall issue" state with regard to permits to carry a handgun and changed Minnesota law with regard to the right to carry and possess a gun on private property within the state. ${ }^{34}$ The Minnesota act allowed private establishments to prohibit the possession of guns on their property by posting notices with statutorily mandated language. ${ }^{35}$ At the same time, it prohibited private establishments from banning guns in their parking lots and prevented these establishments from barring their tenants' possession of guns on their rented property. ${ }^{36}$ Places of worship fell within the definition of private establishment and, like other private establishments, had to post "no gun" notices to prevent possession inside the church or in their rented space. ${ }^{37}$

30. See infra notes 196-209 and accompanying text.

31. See Feldman, Religious Minorities, supra note 19, at 251-59.

32. See Smith, 494 U.S at 879; Reynolds v. United States, 98 U.S. 145, 166-67 (1878).

33. Act of May 24, 2005, ch. 83, § 1, 2005 Minn. Laws 441,442 (codified as amended at MinN. STAT. ANN. § 624.714 (West 2009 \& Supp. 2015)).

34. The law had been enacted first in 2003. Act of April 28, 2003, ch. 28, art. 2-3, 2003 Minn. Laws 265, 272-98. It was immediately challenged by religious, charitable, and municipal organizations who argued that the law violated the Minnesota constitution's protection for religious liberty as well as the constitutional requirement that each law contain only one subject. See Unity Church of St. Paul v. State, 694 N.W.2d 585, 590 \& n.2, 600 (Minn. Ct. App. 2005) (affirming the trial court, which struck down the law on that latter ground but did not consider the religious claims). The legislature then reenacted the law and made it retroactive to the date of its initial adoption. Act of May 24, 2005, ch. 83, §1, 2005 Minn. Laws 441, 442 (codified as amended at MINN. STAT. ANN. $\$ 624.714$ (West 2009 \& Supp. 2015)).

35. MinN. STAT. ANN. § 624.714(17)(a)-(b) (West 2009 \& Supp. 2015).

36. Id. $\S 624.714(17)(\mathrm{c}),(\mathrm{e})$.

37. Id. $\S 624.714(17)(\mathrm{a})-(\mathrm{c})$; Edina Cmty. Lutheran Church v. State, 745 N.W.2d 194, 200-02 (Minn. Ct. App. 2008). 
Two churches challenged the law claiming that it violated the Minnesota constitution's "Freedom of Conscience" provision, ${ }^{38}$ the Federal First Amendment Right of Free Association, ${ }^{39}$ and the federal Religious Land Use and Institutionalized Persons Act (RLUIPA) ${ }^{40}$ The trial court ruled in favor of the plaintiffs on all counts. ${ }^{41}$ The court found that the signage requirement burdened the religious beliefs and practices of the churches by requiring them to parrot a state-mandated message. ${ }^{42}$ The trial court also found that the "parking lot" provision substantially burdened religion. ${ }^{43}$ The state argued that church parking lots should not be given any special religious protection unless they were used as part of a religious celebration. ${ }^{44}$ The court found, however, that parking lots "are integral to [the church's] religious mission." ${ }^{45}$ It would make little sense to allow churches to ban guns in the sanctuary but to

38. MINN. CONST. art. I, $\S 16$ ("Freedom of conscience; no preference to be given to any religious establishment or mode of worship. The enumeration of rights in this constitution shall not deny or impair others retained by and inherent in the people. The right of every man to worship God according to the dictates of his own conscience shall never be infringed; nor shall any man be compelled to attend, erect or support any place of worship, or to maintain any religious or ecclesiastical ministry, against his consent; nor shall any control of or interference with the rights of conscience be permitted, or any preference be given by law to any religious establishment or mode of worship; but the liberty of conscience hereby secured shall not be so construed as to excuse acts of licentiousness or justify practices inconsistent with the peace or safety of the state, nor shall any money be drawn from the treasury for the benefit of any religious societies or religious or theological seminaries.").

39. See, e.g., Boy Scouts of Am. v. Dale, 530 U.S. 640, 647-48 (2000) (holding that the First Amendment includes the right to not associate with others if doing so changes the message of the organization); NAACP v. Alabama ex rel. Patterson, 357 U.S. 449, 460-61 (1958) (stating that the First Amendment to United States Constitution protects right of individuals to associate with one another).

40. Religious Land Use and Institutionalized Persons Act of 2000, Pub. L. No. 106-274, 114 Stat. 803 (codified at 42 U.S.C. $\$ 2000 \mathrm{cc}(2012)$ ).

41. Edina Cmty. Lutheran Church v. State, No. 27-CV-05-11659, slip op. at 5-21 (Minn. Dist. Ct. Nov. 14, 2006), 2006 WL 6111893, aff'd in part and rev'd in part, 745 N.W.2d 194 (Minn. Ct. App. 2008).

42. Id. at 9-10; see also Edina, 745 N.W.2d at 204-05. The churches' pastors' affidavits were sufficient for the court to find a substantial burden on religion. See Edina, No. 27-CV-05-11659, slip op. at 9-10; see also Edina, 745 N.W.2d at 199-200. The state attempted to rebut the harm by arguing that the churches could add additional messages to the signs so long as they still communicated that guns were forbidden. See Edina, No. 27-CV05-11659, slip op. at 10; see also Edina, 745 N.W.2d at 205.

43. Edina, No. 27-CV-05-11659, slip op. at 10-12; see also Edina, 745 N.W.2d at 206-07.

44. See Edina, No. 27-CV-05-11659, slip op. at 11; see also Edina, 745 N.W.2d at 207.

45. Edina, No. 27-CV-05-11659, slip op. at 11. 
be forced to tolerate them in their parking lots. ${ }^{46}$ The court also found that the landlord-tenant provision burdened the churches' religious beliefs because the church's private tenants were there only because they furthered the churches' religious missions. ${ }^{47}$

The Minnesota Court of Appeals upheld the judgment that the law was a violation of the Minnesota constitution's protection of religious freedom. ${ }^{48}$ Unlike the lower standard used under the United States Constitution, ${ }^{49}$ the state used a compelling interest test to determine the law's constitutionality under the state constitution. ${ }^{50}$ The court found that the law substantially burdened the religious beliefs and practices of the churches. ${ }^{51}$ First, the law burdened religion by forcing the churches "to act in a manner that is inconsistent with their religious beliefs by requiring that they place specific, conspicuous signs at every entrance to the church." 52 The law required private establishments not only to post a sign but also to request that anyone who fails to comply leave the premises. ${ }^{53}$ Only at that point could the entrant be prosecuted for trespassing. Both churches were traditional "peace" churches that sought to welcome everyone to their sanctuary and to use church property to further their religious missions. ${ }^{54}$ Moreover, church entrances have a special meaning to Lutherans. ${ }^{55}$ Requiring the church

46. The appellate court also noted that there was ample parking available on public property. Edina, 745 N.W.2d at 209.

47. Edina, No. 27-CV-05-11659, slip op. at 12 ; see also Edina, 745 N.W.2d at 208 . The churches provided rented space for a child care center, services for the homeless, and other community organizations. Edina, 745 N.W.2d at 208.

48. Edina, 745 N.W.2d at 213.

49. See Emp't Div. v. Smith, 494 U.S. 872 (1990).

50. See Minnesota v. Hershberger, 462 N.W.2d 393, 397 (1990) (stating that the Minnesota Constitution protects against incidental burdens on religion); Hill-Murray Fed'n of Teachers v. Hill-Murray High Sch., 487 N.W.2d 857, 864-65 (Minn. 1992) (adopting a fourfactor compelling interest/narrowly tailored test that is more protective of religious freedom than the federal Constitution).

51. Edina, 745 N.W.2d at 213.

52. Id. at 204-05.

53. Id. at 204 (citing MINN. STAT. ANN. $\$ 624.714(17)(b)(1)(\mathrm{i})$-(ii) (2006)).

54. Id. at 203 ("Both churches are committed to peacemaking and nonviolence, to maintaining and providing a place of sanctuary, and to using church property in furtherance of their religious missions."). The state did not challenge the sincerity of the plaintiffs' beliefs. Id. at 205 n.5.

55. Id. at 203-04. Martin Luther posted his Ninety-Five Theses on a church door, sparking the Protestant Reformation. See id. at 200. Entrances to Lutheran churches are associated with not only this historical incident but also the religious liberty associated with Luther and the Protestant reformers. See id. 
to communicate their prohibition of guns and their request to remove the guns constituted a burden on their religion by forcing them to alter these fundamental beliefs. ${ }^{56}$ The parking lot and tenant provisions caused similar burdens. ${ }^{57}$

The court could find no compelling interest in subjecting the churches to the notice, the parking lot, or to the tenant requirement. ${ }^{58}$ Minnesota law required that the state show that individualized religious exemptions would harm public safety. ${ }^{59}$ Although the stated purpose of the law was to protect individual Second Amendment rights to keep and bear arms for self-defense, ${ }^{60}$ the state did not provide any proof that churchgoers were being victimized in their parking lots. ${ }^{61}$ The court also rejected the state's other asserted interests. ${ }^{62}$

Because the court struck down the law under the state constitution, it did not reach the question of the law's constitutionality under the federal Free Exercise Clause. ${ }^{63}$ At one time, federal free exercise claims were adjudicated using a compelling interest/narrowly tailored

56. Id. at 203-05.

57. Id. at 206-08. Church parking lots are used for funeral processions and other mission-related activities. Id. at 206-07. The state proposed a "functional" test that would allow the churches to ban guns when they used their parking lots for religious activities. Id. at 207. The court rejected this option because it would intrude the state even further into religions because the state would have to monitor the churches' activities on their parking lots to determine their religious nature. Id. The tenant provision denied the churches "the opportunity to limit the use of the actual church premises to tenants whose operations are consistent with the churches' commitment to nonviolence and their opposition to the carrying of guns. These are the same facilities where religious services are conducted." Id. at 208.

58. Id. at $209-10$.

59. Id. at 208.

60. See id.

61. Id. at 209 ("[T]he state presented no evidence in the district court that denying an exemption to religious institutions would result in the victimization of citizens at church functions, in church parking lots, or in church building areas used by tenants. The state therefore did not show that religious practices, including the religious-based exclusion of weapons from church property and activities, are actually 'inconsistent with public safety." (quoting Minnesota v. Hershberger, 462 N.W.2d 393, 398 (1990)).

62. The state claimed that the parking lot provision of the law advanced the right to travel while the message provision ensured that citizens received clear and adequate information about their gun rights. Id. As for the former, the court noted that adequate onstreet parking was available. Id. As for the latter, the court noted that colleges and universities had considerable flexibility to communicate their policies relating to the possession of weapons on school property. Id.

63. Id. at 210. It did, however, hold that the law was not a land-use regulation and therefore was not subject to the Religious Land Use and Institutionalized Persons Act. Id. 
standard. ${ }^{64}$ In Employment Division v. Smith, the Supreme Court rejected the compelling interest standard ${ }^{65}$ In its place, it substituted what seemed like a straightforward standard. Neutral and generally applicable laws that only incidentally burdened religion will be analyzed under a rational basis test. ${ }^{66}$ A statute receives heightened scrutiny only if it targets religion or religious practice. ${ }^{67}$ Congress responded to the Smith case by adopting the Religious Freedom Restoration Act (RFRA), which purported to restore the compelling interest/narrowly tailored test. ${ }^{68}$ The United States Supreme Court struck down RFRA because it exceeded Congress's Fourteenth Amendment enforcement power ${ }^{69}$ Congress then enacted the Religious Land Use and Institutionalized Persons Act, which restored the compelling interest

64. See Thomas v. Review Bd., 450 U.S. 707, 718-19 (1981) (noting that the state may burden religion only if it pursues a compelling government interest with the least restrictive alternative); Wisconsin v. Yoder, 406 U.S. 205, 215 (1972) ("[O]nly those interests of the highest order ... can overbalance legitimate claims to the free exercise of religion."); Sherbert v. Verner, 374 U.S. 398, 406 (1963) ("It is basic that no showing merely of a rational relationship to some colorable state interest would suffice; in this highly sensitive constitutional area, " $[0]$ nly the gravest abuses, endangering paramount interests, give occasion for permissible limitation." (alteration in original) (quoting Thomas v. Collins, 323 U.S. 516, $530(1945))$ ).

65. Emp't Div. v. Smith, 494 U.S. 872 (1990) (holding that neutral and generally applicable laws do not violate Free Exercise Clause).

66. See id. Smith was exceptionally controversial. See, e.g., Douglas Laycock, The Supreme Court's Assault on Free Exercise, and the Amicus Brief That Was Never Filed, 8 J.L. \& Religion 99 (1990); Steven D. Smith, Free Exercise Doctrine and the Discourse of Disrespect, 65 U. COLO. L. REV. 519 (1994). But see William P. Marshall, In Defense of Smith and Free Exercise Revisionism, 58 U. CHI. L. REV. 308 (1991).

67. See Church of the Lukumi Babalu Aye, Inc. v. City of Hialeah, 508 U.S. 520, 532 (1993) ("At a minimum, the protections of the Free Exercise Clause pertain if the law at issue discriminates against some or all religious beliefs or regulates or prohibits conduct because it is undertaken for religious reasons."); see also Richard F. Duncan, Free Exercise and Individualized Exemptions: Herein of Smith, Sherbert, Hogwarts, and Religious Liberty, 83 NEB. L. REV. 1178, 1203 (2005) ("[S]trict scrutiny will apply if the religious-liberty claimant establishes two things: (1) that the State has in place an individualized process or system for allocating governmental benefits or burdens and (2) that his or her religious-liberty claim has been rejected under the ad hoc scheme.").

68. Religious Freedom Restoration Act of 1993, Pub. L. No. 103-141, 107 Stat. 1488 (codified at 42 U.S.C. $\$ 2000 \mathrm{bb}-1$ (2012)).

69. City of Boerne v. Flores, 521 U.S. 507 (1997) (holding that Religious Freedom Restoration Act exceeded Congress's power to enforce violations of the Fourteenth Amendment). Flores, like Smith, seemed to break with prior cases in this area. See, e.g., John M.A. DiPippa, The Death and Resurrection of RFRA: Integrating Lopez and Boerne, 20 U. ARK. LITTLE ROCK L.J. 767, 771 (1998); Douglas Laycock, The Religious Exemption Debate, 11 Rutgers J.L. \& ReLIGION 139, $141-44$ (2009) [hereinafter Laycock, Religious Exemption]. 
test only for land-use regulations and burdens on institutionalized persons. $^{70}$

In GeorgiaCarry.org, Inc. v. Georgia, several individuals, a gun rights organization, and a Baptist church challenged a Georgia law that prohibited the possession of weapons in a "place of worship."71 The individual plaintiffs claimed that the law violated their First Amendment right to the free exercise of religion. ${ }^{72}$ They argued that the law violated their rights by "prohibiting them from engaging in activities in a place of worship when those activities are generally permitted throughout the state."73 Although the Eleventh Circuit found that the plaintiffs had standing ${ }^{74}$ it concluded that they failed to state a free exercise challenge because they omitted any factual matter that pointed to a burden on a sincerely held religious belief. ${ }^{75}$ The court noted that the First Amendment does not protect personal preferences or secular beliefs ${ }^{76}$ and the plaintiffs failed to distinguish their personal preference to be armed from any religious duty to carry weapons:

70. Religious Land Use and Institutionalized Persons Act of 2000, Pub. L. No. 106-274, 114 Stat. 803 (codified at 42 U.S.C. $\$ 2000 \mathrm{cc}(2012)$ ). The original RFRA still applies to the actions of the federal government. See Gonzales v. O Centro Espirita Beneficente Uniao do Vegetal, 546 U.S. 418, 424 (2006) ("Under RFRA, the Federal Government may not, as a statutory matter, substantially burden a person's exercise of religion, 'even if the burden results from a rule of general applicability."' (quoting 42 U.S.C. \$ 2000bb-1(a) (2000))). RFRA has taken on a higher profile with recent litigation over insurance requirements imposed by the Patient Protection and Affordable Care Act. See Patient Protection and Affordable Care Act, Pub. L. No. 111-148, 124 Stat. 119, 131 (codified at 42 U.S.C. $\$ 300 \mathrm{gg}-$ 13(a)(4) (2012)) (establishing minimum coverage requirements for insurance plans including certain contraceptive services); Coverage of Certain Preventative Services Under the Affordable Care Act, 78 Fed. Reg. 39,870, 39,873-82 (July 2, 2013) (codified as amended at 45 C.F.R. § 147.131(2013)) (establishing a religious organizations exemption from paying for contraceptive services, provided they certify their status); see also Ave Maria Found. v. Sebelius, 991 F. Supp. $2 d 957$ (E.D. Mich. 2014) (suggesting that the certification requirement imposed by federal health care law violates Religious Freedom Restoration Act); E. Tex. Baptist Univ. v. Sebelius, 988 F. Supp. 2d 743 (S.D. Tex. 2013) (discussing the Act's requirements and the development of the regulations concerning religious organizations).

71. GeorgiaCarry.org, Inc. v. Georgia, 687 F.3d 1244, 1249 n.8 (11th Cir. 2012). The Georgia statute made it a misdemeanor to carry a "weapon or a long gun" in a place of worship. GA. CODE ANN. §16-11-127(b) (2011 \& Supp. 2013).

72. GeorgiaCarry.org, 687 F.3d at 1255.

73. Id.

74. Id. at 1252. The plaintiffs' fear of prosecution satisfied the injury-in-fact requirement of standing. See id. The plaintiffs' "serious intent" to violate the statute and the state's intention to enforce it creates the injury necessary for standing. Id.

75. Id. at 1255 .

76. Id. at 1256 ("The Supreme Court has reiterated time and time again that personal preferences and secular beliefs do not warrant the protection of the Free Exercise Clause."). 
We searched the Amended Complaint to no avail in an attempt to find factual allegations that could possibly be construed as alleging that the Carry Law imposes a constitutionally impermissible burden on one of Plaintiffs' sincerely held religious beliefs. At various points, Plaintiffs allege that they would like to carry a handgun in a place of worship for the protection either of themselves, their family, their flock, or other members of the Tabernacle. Plaintiffs conclude by alleging that the Carry Law interferes with their free exercise of religion by prohibiting them from engaging in activities in a place of worship when those activities are generally permitted throughout the State. That Plaintiffs "would like" to carry a firearm in order to be able to act in "self-defense" is a personal preference, motivated by a secular purpose. As we note supra, there is no First Amendment protection for personal preferences; nor is there protection for secular beliefs. ${ }^{77}$

The plaintiffs argued that they did not have to show a burden when a law was not neutral. ${ }^{78}$ They asserted that the law could not be neutral as to religion if it specifically set houses of worship apart from other secular property, but according to the court, this mischaracterized existing Free Exercise Clause precedent. ${ }^{79}$ A free exercise complaint will be dismissed if it "does not allege that (1) the plaintiff holds a belief, not a preference, that is sincerely held and religious in nature, not merely secular; and (2) the law at issue in some way impacts the plaintiff's ability to either hold that belief or act pursuant to that belief." 80

Litigants like the ones in GeorgiaCarry.org will have trouble articulating their claim in religious terms. What exactly is the nature of the claim? Is it to be armed in general or is it to be armed in church? Is there a symbolic meaning to carrying weapons in general or specifically into a place of worship? It may have a basis in a deeply felt cultural or social imperative, but unless they can point to some theological basis or religious practice to explain how a ban on gun possession interferes with their religious practice, neither the Free Exercise Clause nor federal law will come into play. ${ }^{81}$ This is where the Georgia plaintiffs foundered.

77. Id. at 1258 .

78. Id. at 1255 .

79. Id. at 1255-56.

80. Id. at $1256-57$.

81. See id. 
They are undoubtedly correct that the law set religion apart, but they fail the threshold question of whether or not a law burdens a religious practice. In any event, the Eleventh Circuit seemed skeptical of their claim. ${ }^{82}$

On the other hand, the Minnesota court had no difficulty finding a religious burden. ${ }^{83}$ Indeed, the state did not challenge the religious claim and the existence of a burden seemed almost self-evident to the court. ${ }^{84}$ Yet deciding what is a religious burden is difficult task that is not supposed to turn on the court's "perception of the particular belief or practice in question; religious beliefs need not be acceptable, logical, consistent, or comprehensible to others in order to merit First Amendment protection." 85 "Courts should not ... dissect religious beliefs because the believer admits that he is 'struggling' with his position or because his beliefs are not articulated with the clarity and precision that a more sophisticated person might employ." ${ }^{86}$

\section{THE RELEVANCE OF SIKHS AND KIRPANS}

While the Baptist plaintiffs in GeorgiaCarry.org had trouble connecting weapon possession to religious beliefs, Sikhs can make that claim easily. Their problem, however, is that it must be sanitized and tamed to receive protection. Sikh men are required to have in their possession five items, one of which is a curved dagger or sword. ${ }^{87}$ Here the religious adherent can persuasively argue that the possession of the weapon is itself a religious practice. ${ }^{88}$ A Sikh man can easily show that a weapon ban substantially burdens his religious practice. The fit between the state's means and ends becomes the most critical part of the analysis.

82. See id. at 1255 ("Plaintiffs allege that the Carry Law 'interferes with the free exercise of religion by Plaintiffs by prohibiting them from engaging in activities in a place of worship when those activities are generally permitted throughout the state.' This so-called prohibition applies to anyone who enters a place of worship-regardless of the person's religious preference." (citation omitted)). This seems to conflate the question of religious burden with the question of the law's neutrality. The question is not whether the law applies to a person with a different belief about carrying weapons. See id. at 1256-57. The question is whether or not the law burdens this particular plaintiff's religious beliefs. See id.

83. Edina Cmty. Lutheran Church v. State, 745 N.W.2d 194 (Minn. Ct. App. 2008).

84. Id. at 203-08.

85. Thomas v. Review Bd., 450 U.S. 707, 714 (1981).

86. Id. at 715 .

87. See Baker, supra note 21, at 15-16; Dipanwita Deb, Note, Of Kirpans, Schools, and the Free Exercise Clause: Cheema v. Thompson Cuts Through RFRA's Inadequacies, 23 HASTINGS CONST. L.Q. 877, 881-82 (1996).

88. Deb, supra note 87 , at $881-82$. 
There is considerable litigation, for example, concerning the requirement for facial hair, especially in the employment and prison contexts. $^{89}$

In Cheema $v$. Thompson, the Ninth Circuit found a school district's weapons ban burdened Sikh children's religious beliefs. ${ }^{90}$ The children's parents challenged the school district's total ban on all weapons. ${ }^{91}$ Because the district believed that state law prohibited the possession of knives on school property, it banned kirpan possession. ${ }^{92}$ According to the court, "[t]his left the Cheema children with two choices if they wished to attend school: either leave their kirpans at home (and violate a fundamental tenet of their religion) or bring them to school (and face expulsion and/or criminal prosecution)." 93 The children remained away from school while their parents challenged the ban under the Religious Freedom Restoration Act. ${ }^{94}$

There was no question that the ban burdened a sincerely held religious belief. ${ }^{95}$ Unlike the Baptist plaintiffs in Georgia, the Sikh children could point to a centuries-old, well-articulated tradition requiring the possession of the kirpan. ${ }^{96}$ Although the school district

89. See, e.g., Holt v. Hobbs, 135 S. Ct. 853 (2015); Dawinder S. Sidhu, Religious Freedom and Inmate Grooming Standards, 66 U. MIAMI L. REV. 923 (2012).

90. Cheema v. Thompson, 67 F.3d 883, 885-86 (9th Cir. 1995); see Deb, supra note 87, at $885-86$. The Canadian Supreme Court reached the same conclusion as the Cheema court. See Multani v. Comm'n scolaire Marguerite-Bourgeoys [2006] 1 S.C.R. 256, 2006 SCC (Can.) (stating that a complete ban on weapon possession in schools violated a Sikh child's freedom of religion); see also BRIAN LEITER, WHY TOLERATE RELIGION? 1-4 (2013) (arguing against accommodating the kirpan in schools); Mark S. Kende, Free Exercise of Religion: $A$ Pragmatic and Comparative Perspective, 55 S.D. L. REV. 412, 419-21 (2010) (discussing Multani in comparing Canadian courts' approach in religion cases to that of South Africa and the United States); Allison N. Crawford, Note, Learning Lessons from Multani: Considering Canada's Response to Religious Garb Issues in Public Schools, 36 GA. J. INT'L \& COMP. L. 159 (2007). This Article excludes those decisions that have upheld kirpan bans in airports and other places where security concerns will trump all other issues. Rather, this Article focuses on those locations where security, while important, is not paramount and subject to some accommodation.

91. Cheema, 67 F.3d at 885 .

92. Id. at 884 .

93. Id.

94. Id. at 884-85.

95. Id. at 885 . Even the dissent agreed completely on this point. See id. at 889 (Wiggins, J., dissenting) ("It is clear that the District's no-knives policy ... substantially burdens [the children's] free exercise of their religion."). (1996).

96. Amarjeet S. Bhachu, Note, A Shield for Swords, 34 AM. CRIM. L. REV. 197, 200-03 
had a compelling interest in campus safety, the court held that there were less restrictive alternatives to a total ban:

But we simply could not conclude that nothing short of a wholesale ban would adequately protect student safety. The problem was a total failure of proof; the school district refused to produce any evidence whatever to demonstrate the lack of a less restrictive alternative. ${ }^{97}$

The court noted that other school districts had successfully accommodated Sikh children without sacrificing student safety. ${ }^{98}$ The court upheld the lower court's injunction that allowed kirpan possession in schools under the following conditions: that the kirpan have a dull blade, is about three and one-half inches in length, and is sewn into its sheath and worn under clothing. ${ }^{99}$ These policies apparently were aimed at making the kirpan unavailable for use by either literally blunting it or making it inaccessible. The dissent argued that this accommodation did not serve the district's interest in safety. ${ }^{100}$ The knives are unquestionably dangerous. Even when sewn to their sheaths, they can still be removed. ${ }^{101}$

97. Cheema, 67 F.3d at 885. Cheema was decided prior to City of Boerne v. Flores, where the Supreme Court struck down the Religious Freedom Restoration Act, at least as it applied to actions by state and local governments. City of Boerne v. Flores, 521 U.S. 507, 508 (1997). RFRA required that state and local government actions that substantially burden a sincerely held religious belief must be the least restrictive way to advance a compelling state interest. Cheema, 67 F.3d at 888 (Wiggins, J., dissenting). Today, because the weapons ban is facially neutral as to religion and generally applicable to all students, the school district would probably only have to show that the weapons ban was reasonably related to a legitimate state interest in order to survive a free exercise challenge. See Emp't Div. v. Smith, 494 U.S. 872 (1990). Nevertheless, the case illustrates the recurring problems with religious freedom claims and the shifting nature of neutrality. Of course, developments in Second Amendment law provide new legal obstacles to weapons bans. See McDonald v. City of Chicago, $130 \mathrm{~S}$. Ct. 3020 (2010); District of Columbia v. Heller, 554 U.S. 570 (2008).

98. Cheema, 67 F.3d at 885 n.3.

99. Id. at 886 .

100. Id. at 890-91 (Wiggins, J., dissenting) ("The district court was presented with an affidavit from a school secretary who was able to observe Jaspreet Cheema's (supposedly unnoticeable) kirpan. Worse still, she observed that Jaspreet's 4 year-old brother was wearing one, too. And, most alarmingly, the secretary stated that Jaspreet told her that 'if anybody steals from me, I can put this to them.' While making this statement, he grabbed his kirpan.").

101. Id. at 891 . 
Moreover, there was no evidence that the children in question were any more mature than other children their age and, therefore, should not have knives available to them during the school day. ${ }^{102}$

What was more intriguing about the dissent, however, was its direct analysis of the nature of the actual religious belief at issue. Kirpans symbolize a Sikh's desire to do "God's Justice." 103 Expert testimony at trial indicated that the weapon was not simply symbolic. ${ }^{104}$ Indeed, a useless weapon would not serve its religious purpose. Sikhs must carry a kirpan so that is can be used to defend their religion. ${ }^{105}$ According to plaintiff's expert, only real, functional knives could satisfy the religious duty to carry the weapon. ${ }^{106}$ Neither carrying a symbolic kirpan nor riveting it into its sheath would satisfy the religious duty to be armed. ${ }^{107}$ Those changes "would alter it and destroy its character as a kirpan. A kirpan is a knife, not a knife and sheath combination."108

The dissent looked at the knife objectively and not through the subjective, religious lens of the Sikh believer. ${ }^{109}$ If the kirpan is a knife, then the school district has the right to ban its possession regardless of its religious significance to Sikh believers. ${ }^{110}$ Viewed from this perspective, the proposed accommodations were incoherent and ineffective. The injunction allowed the children to carry the weapon if it was sewn into the sheath and worn under the clothing. ${ }^{111}$ But as the plaintiff's expert pointed out, this did not render the knife

102. The dissent pointed out at least two instances where the children had taken their knives out of their sheaths. Id. In one instance, they were trying to cut the rope on the flag pole. Id. In a similar vein, a teacher claimed that she saw the Sikh children attempting to hoist a kirpan up the flag pole. Id.

103. Id. at 887 .

104. Id. at 890 .

105. Bhachu, supra note 96 , at 203 ("The kirpan, then, is not only part of the identity of a Khalsa Sikh, but an instrument of self-defense.").

106. Cheema, 67 F.3d at 890 (Wiggins, J., dissenting).

107. See id.

108. Id. (internal quotation mark omitted).

109. Id. ("[W]hile a knife can indeed be a kirpan, and thus have deep spiritual meaning to a Sikh, this does not change the fact that the underlying object is, still, a knife. In other words, I would allow the school district, and the district court, to look at what an object is objectively, rather than through the subjective eyes of a claimant."); see also MARCI A. HAMILTON, GOD VS. THE GAVEL: RELIGION AND THE RulE OF LAW 116 (2005) (stating that the dissent considered third party interests along with believer's interests).

110. See Cheema, 67 F.3d at 890 (Wiggins, J., dissenting).

111. Id. at 886 (majority opinion). 
inaccessible. ${ }^{112}$ The lower court and the plaintiffs seemed to suggest that the kirpan was somehow not a knife, but as the dissent pointed out, this conclusion was belied by the plaintiff's own experts. ${ }^{113}$ Common sense and religious belief both point to one conclusion: A knife is a knife. When combined with another required item - the kara - the conclusion is inescapable: the kirpan is a weapon whose religious significance lies in its availability to be used in defense of the faith. ${ }^{114}$

The district court relied on the accommodations that other school districts had in place to find that a total ban violated RFRA. ${ }^{115}$ But, as the dissent pointed out, those districts took more assertive measures to ensure that the kirpan was rendered unusable. ${ }^{116}$ If the dissent was correct, these other policies did not support the more expansive policy approved by the district court.

Moreover, they also point out the intractability of religious accommodations in this circumstance. The other school districts essentially changed the nature of the kirpan from an actual weapon

112. See id. at 890-91 (Wiggins, J., dissenting).

113. Id.

114. See id. at 890 . The dissent argued that the actual religious belief and practice required that the kirpan be a real weapon capable of use in defense of the faith. Id. The dissent pointed to the affidavit of the plaintiff's expert who, "although unintentionally, revealed that even through the eyes of a Sikh, a kirpan is indeed a weapon." Id. While the expert stated that a kirpan "'would never be regarded [as a weapon] by a Khalsa Sikh,' he referred to the kirpan as 'sword' and a 'knife." Id. (alteration in original). "He explained that '[a] kirpan must be made of steel and have a curved blade. It is not particularly sharp, although it is an actual knife or dagger." Id. (alteration in original). The expert "explained that another requirement of Khalsa Sikhs is that they wear a steel bracelet, called a kara, at all times, 'to remind that the sword [kirpan] is to be used only in self defense and the propagation of justice." Id. (alteration in original); see also Jeremy Waldron, One Law For All? The Logic of Cultural Accommodation, 59 WASH. \& LEE L. REV. 3, 7 (2002) ("In fact, the Sikh's religious obligation is an obligation to present himself in public as a combination of saint and warrior.").

115. See Cheema, 67 F.3d at 892 (Wiggins, J., dissenting).

116. Id. at 892 . The dissent noted that

[t]wo of the three "examples of accommodation" to which the majority referred involved school districts that only allowed kirpans if the two restrictions the District forwarded in the present case were followed. Both Yuba City and Live Oak Unified School Districts only allow kirpans that are no longer than 3 inches in total length, and even those must be riveted to their sheaths. The third school district to which the majority referred has different restrictions (a rounded tip and a blunted edge), that accomplish the same thing: the kirpan is rendered a non-functional knife.

Id. 
available for defensive use to a mere symbol. ${ }^{117}$ It made it so that the kirpan could no longer serve its actual religious purpose. In Cheema, the Sikh plaintiffs even argued that the kirpan was not really a knife or a weapon. ${ }^{18}$

The Sikh claim and the dissent's skepticism illustrate the inherent tension in religious freedom law. Most religious claims are subjective. That is, they rely on faith in an unseen reality or symbolic actions that express a religious truth. ${ }^{119}$ Their religious significance disappears when that lens is removed and they are viewed "objectively." 20 The other school district's accommodations were typical of the way that minority religions must dilute their beliefs to gain accommodation or

117. See Waldron, supra note 114 , at 7 ("[T] that the kirpan is carried by the Sikh initiate purely as a matter of religious observance, as though its ceremonial significance had nothing to do with its significance as a weapon.").

118. Cheema, 67 F.3d at 890 .

119. Take, for example, the Roman Catholic practice of lighting candles during special services. See The Roman Missal and the Easter Vigil, U.S. CONF. CATHOLIC BISHOPS, http:// www.usccb.org/prayer-and-worship/liturgical-year/triduum/roman-missal-and-the-easter-vigil. cfm (last visited Mar. 25, 2015), archived at http://perma.cc/3NS2-CZ6Q. The Easter Vigil service, for example, begins in darkness. Id. The priest solemnly enters the church carrying the Paschal candle, a large candle symbolizing that Jesus is the light of the world. See id. The congregation holds individual candles, which are lit from the single flame of the Paschal candle. See id. The people pass this light from candle to candle until all the candles are lit. See id. These remain the only source of light until later in the service, when they are extinguished and the church lights are dramatically turned on. See id. To the believer, this expresses deep and important meaning. See id. The candles are more than burning wicks, but to an objective fire inspector, they are a potential fire hazard. See, e.g., Sonja Barisic, Symbol of Salvation, or Fire Hazard? Fire Marshal Bans Candles Held by Worshipers, LUDINGTON DAILY NEWS, Apr. 8, 1993, at 2, available at http://news.google.com/newspapers?nid=110\&da $\mathrm{t}=19930408 \& \mathrm{id}=7$ LcLAAAAIBAJ\&sjid=3IUDAAAAIBAJ\&pg=7268,544463, archived at ht tp://perma.cc/JZN2-D97V; Easter Vigil Dispute: Archbishop Appeals Hand-Held Candle Ban, BEAVER CNTY. TIMES, Apr. 8, 1993, at A1, available at http://news.google.com/newspapers?n id=2002\&dat=19930408\&id=27QiAAAAIBAJ $\&$ sjid=ErUFAAAAIBAJ \&pg=4923,1623939,

archived at http://perma.cc/3BBD-RSV5. It is probable that cities have granted exemptions for such services, but this only illustrates a further problem: majority religions find it easy to acquire accommodations for this practice even if "objectively" dangerous, while minority religions may not be so successful.

120. For example, Roman Catholics believe that the consecrated host is the real body of Jesus Christ. See The Real Presence of Jesus Christ in the Sacrament of the Eucharist: Basic Questions and Answers, U.S. CONF. CATHOLIC BISHOPS, http://www.usccb.org/prayer-and-w orship/the-mass/order-of-mass/liturgy-of-the-eucharist/the-real-presence-of-jesus-christ-in-the -sacrament-of-the-eucharist-basic-questions-and-answers.cfm (last visited Mar. 25, 2015), archived at http://perma.cc/WKY2-FPG8. Objectively, the host is a wafer of unleavened bread, but the believer does not treat it as such. Rather, the belief in the Real Presence compels believers to act reverently toward the host and to take steps to prevent its misuse or destruction. Id. But seen from the dissent's perspective, the host remains a dry wafer and that is how the law should see it. 
acceptance. ${ }^{121}$ Indeed, the policy in the reported decision illustrates this, too. The school district's accommodations suggested that they believed they had "neutralized" the knives' danger without also recognizing that truly doing so emptied the practice of religious significance.

Brian Leiter uses the kirpan example as a central feature of his position that religious practices should not be given special constitutional exemptions from general laws. ${ }^{122}$ Leiter posits two hypothetical boys: one boy, a Sikh who carries a knife to fulfill a religious obligation, and the other boy, a young man in a rural community who is given a knife as a cultural rite of passage to manhood. ${ }^{123}$ Leiter is puzzled by the different treatment these boys would receive if they sought to bring their knives to school:

There is no Western democracy, at present, in which the [rural] boy ... has prevailed or would prevail in a challenge to a general prohibition on the carrying of weapons in the school. Were he a Sikh he would stand a good chance of winning. But if he can only appeal to a century-old tradition, central to his identity, to which he feels categorically bound by his family traditions and upbringing, he is out of luck. ${ }^{124}$

Leiter notes that the Multani decision upheld the right of the Sikh children to wear real knives if they held a sincere personal and religious belief in its importance. ${ }^{125}$ The court noted the unique characteristics of schools that distinguished them from places like courthouses and airports, where the kirpan could be banned. ${ }^{126}$ Yet, as Leiter points out, the court failed to consider those circumstances in which schools may be uniquely vulnerable to violence from weapons carried on students'

121. See Cheema, 67 F.3d at 892 (Wiggins, J., dissenting). Religious belief and practice must often be sanitized, tamed, or modified. See Stephen M. Feldman, A Christian America and the Separation of Church and State, in LAW AND RELIGION: A CRITICAL ANTHOLOGY 261, 262-66 (Stephen M. Feldman ed., 2000) [hereinafter Feldman, Christian America].

122. LEITER, supra note 90 , at 64-67.

123. Id. at $1-3$.

124. Id. at 3 .

125. Id. at 64-65; see also Multani v. Comm'n scolaire Marguerite-Bourgeoys [2006] 1 S.C.R. 256 (Can. S.C.C.).

126. See Multani v. Comm'n scolaire Marguerite-Bourgeoys, [2006] 1 S.C.R. 256 (Can. S.C.C.) (declaring that schools are partnerships that can control their environment better than other public spaces); LEITER, supra note 90, at 64-66. 
persons. ${ }^{127} \mathrm{He}$ cannot see why the justifications for banning the kirpan in other places do not apply equally to schools. ${ }^{128}$ And, if the Sikh child can carry a real knife in school, then he cannot see any difference with the sincere claim of the rural child to carry his knife. ${ }^{129}$ Ultimately, he concludes that the two boys should be treated the same and that they should both lose..$^{130}$ Religious exemptions from general laws should not be granted "unless those exemptions do not shift burdens or risks onto others." $" 131$

Leiter's principle suggests a different approach in the GeorgiaCarry.org and Edina cases. Not only can the plaintiffs rely on a sustained and sincere tradition (especially in the south), they have also built their claim on a religious foundation. ${ }^{132}$ The right (if not the duty) of self-defense is well established in Christian theology. ${ }^{133}$ Granting them an exemption from the gun law would not shift the burden to anyone else. Unlike children who are compelled to be in school, no adult is forced to attend any particular church. ${ }^{134}$ Churchgoers who object to fellow members being armed are free to find a church with beliefs and practices more compatible with their own.

Even if the right is not religious in nature, it points out how problematic it is for courts to distinguish religious beliefs from convictions of conscience. In GeorgiaCarry.org, the church's desire to be armed for self-defense grew out of not only a long tradition but also a shooting in a nearby church. ${ }^{135}$ Their desire could be a religious belief or a conviction of conscience, deeply and sincerely held, as well as a secular preference for safety. Leiter is skeptical that religious claims should be

127. LEITER, supra note 90 , at 65-66 (noting the general lack of armed guards, the immaturity of the students, and the natural and inevitable "antagonistic relationships" among students and between faculty and students).

128. Id. at 66.

129. See id. at $66-67$ (" $[\mathrm{T}]$ here is no principled reason for legal or constitutional regimes to single out religion for protection.").

130. Id. at 4 .

131. Id.; see also HAMILTON, supra note 109 , at 116 (criticizing the Cheema majority for "thinking only in terms of the needs of the believer").

132. I will assume its sincerity for the moment.

133. See infra Part V.

134. Of course, children are present during a worship service, but they are typically in a room surrounded by adults, the exact opposite of the makeup of elementary and secondary schools.

135. See Whitman, supra note 12 , at $1988-89$. 
given special exemptions when secular claims of conscience will not. ${ }^{136}$ In the end, Leiter's counsel is to limit the reach of religious exemptions because a principled application of a broad exemption for conscience would include so many claims that it "would appear to amount to a legalization of anarchy." 137

On the other hand, the Edina churches' claims for exemptions from the signage and request requirements set religion apart from every other private establishment. ${ }^{138}$ The law imposed little additional burden on the religious establishment that other private establishments did not share. Rather, their religious claim allowed them to be set apart from a law that everyone else had to follow. Per Leiter, there is no principled way to justify this exception, especially when the burden on religious practice is almost non-existent. ${ }^{139}$

When it comes to possession of a kirpan, however, the more precise the believer articulates his belief, the less likely he is to gain protection. The Sikh plaintiffs in Cheema and their fellow Sikhs in the other schools mentioned in the opinion had to water down the significance of the kirpan in order to carry it in schools. ${ }^{140}$ If they had claimed that the religious significance of the kirpan was that it be available for use in selfdefense, they would have lost their case. Religious gun owners face a similar challenge. Unlike the Sikh's, the GeorgiaCarry.org plaintiffs could not articulate a clear theological or historical justification for gun possession in church. ${ }^{141}$ Rather, as the Eleventh Circuit pointed out, they were left asserting what sounded like a personal preference. ${ }^{142}$ There is a religious argument for gun possession, but articulating it will drag courts into evaluating the reasonableness of the religious belief, a place where courts do not want to go. ${ }^{143}$

136. See LEITER, supra note 90 , at 94-97.

137. Id. at 94 .

138. Edina Cmty. Lutheran Church v. State, 745 N.W.2d 194 (Minn. Ct. App. 2008).

139. LEITER, supra note 90 , at 54-67.

140. See Cheema v. Thompson, 67 F. 3d 883, 895 (9th Cir. 1995) (Wiggens, J., dissenting); see also id. at 884 (majority opinion) (describing the kirpan as a "ceremonial knife").

141. GeorgiaCarry.org, Inc. v. Georgia, 687 F.3d 1244, 1255-58 (11th Cir. 2012).

142. Id. at 1258.

143. See, e.g., Emp't Div. v. Smith, 494 U.S. 872, 886-87 (1990) (stating that courts should not determine plausibility or place of religious claim); Hernandez v. Comm'r, 490 U.S. 680,699 (1989) (arguing that the judiciary is not competent to determine centrality of religious belief or practice); Thomas v. Review Bd., 450 U.S. 707, 714-16 (1981) (stating that the judiciary should not ask whether a claimant's religious understanding is correct). 


\section{IS THERE A RELIGIOUS DUTY OF SELF DEFENSE?}

David Kopel argues for a religious duty of self-defense, a duty that presumably prevents states from prohibiting gun possession..$^{144} \mathrm{He}$ accurately, if tendentiously, ${ }^{145}$ relates the history of the traditional Christian reliance on the just war theory. ${ }^{146} \mathrm{He}$ argues that Western Christianity's recent emphasis on "pacifism" is a departure from traditional doctrine. ${ }^{147} \mathrm{He}$ concludes that, at least in the Roman Catholic tradition, "states and families" have a religious duty of selfdefense. ${ }^{148} \mathrm{He}$ relies on Vatican documents that discuss this duty in the context of governments intervening in other states to prevent abuses of human rights. ${ }^{149}$ Indeed, these very documents approve gun control measures for individuals. ${ }^{150} \mathrm{Kopel}$ agrees with the documents until this point where he interposes secular constitutional rights to bear arms to refute the Vatican's conclusion. ${ }^{51}$ Kopel conflates the duty of civil authorities to defend their people with the duty of individuals to be armed. ${ }^{152}$ One can agree that an individual may act in self-defense without also concluding that that individual must be armed at all times.

At the same time, Kopel correctly points out that mainstream religions have always approved of the use of force in some circumstances, not the least of which was for individual self-defense. ${ }^{153}$ To that extent, churches like those in the Edina case have weaker religious claims than the plaintiffs in GeorgiaCarry.org. This is a disagreement among Christians about the interpretation of Scripture and Tradition, the authority of institutional interpretation as opposed to individual interpretation, and the relative importance of one over the other. ${ }^{154}$ In other words, these are religious disputes. To resolve them, one must engage the materials and come to a religious conclusion. The

144. Kopel, Evolving Attitudes, supra note 20, at $1764-65$ ("[A]rmed defense was a "right" and a "duty" for families and for nations.").

145. Id. at 1763 (describing the 2003 military action in Iraq as a "liberation")

146. Id. at $1714-19$.

147. Id. at 1769 ("[T]oday pacifism has greater respectability within orthodox Christianity than any time in the past 1700 years.").

148. See id. at 1764-65.

149. Id. at $1764-66$.

150. Id. at 1765 .

151. Id. at $1765-66$.

152. See id.

153. Id. at 1714-19.

154. See Kopel, Evolving Attitudes, supra note 20 
problem, of course, is that this is exactly what courts should not do in free exercise cases.

\section{RELIGIOUS LIBERTY ISSUES IN CATEGORICAL AND OPT-OUT JURISDICTIONS}

In categorical jurisdictions, places of worship feel singled out because the law specifically excludes religious property. ${ }^{155}$ State laws that categorically prohibit the possession of guns in churches are not neutral as to religion. That is, unlike laws that treat churches the same as any other private property owner, categorical exclusions carved out a special exception for churches.

Other pieces of property are also categorically excluded. Often statutes will prohibit possession of guns not only in churches but also in schools, government buildings, and other places where large groups may gather. ${ }^{156}$ This suggests that there are non-religious reasons for prohibiting gun possession in churches. The state may argue health and safety, ease of enforcement, or other similar arguments. ${ }^{157}$ Churches will claim, however, that they are singled out because they vary so widely in their size, location, and practice. ${ }^{158}$ That is, the other places categorically excluded all have similar features. For example, schools will not vary largely in size. They will all contain minors or vulnerable individuals, and they all house people for considerable periods of the day. Churches, on the other hand, range in size from the mega church to the living room church. Moreover, these churches will have vastly different missions and vastly different practices. For some, it would be unthinkable to allow their members to be armed. ${ }^{159}$ But for others the question may be much closer. ${ }^{160}$ Thus, they argue that the categorical exclusion of churches is not neutral as to religion because it privileges one particular theology about weapons and peace. ${ }^{161}$

In opt-out jurisdictions, however, gun laws are neutral as to religion. For example, the Minnesota concealed carry law does not single out

155. See, e.g., GeorgiaCarry.org, Inc. v. Georgia, 687 F.3d 1244, 1255 (11th Cir. 2012).

156. E.g., GA. CODE ANN. § 16-11-127(b) (2011 \& Supp. 2013).

157. See, e.g., Edina Cmty. Lutheran Church v. State, 745 N.W.2d 194, 208-09 (Minn. Ct. App. 2008).

158. See, e.g., id. at 212-13.

159. See, e.g., Edina, 745 N.W.2d at 203.

160. See, e.g., GeorgiaCarry.org, 687 F.3d at 1249 n.8.

161. See id. at $1255-59$. 
churches. ${ }^{162}$ Rather, it includes churches in the general description of private establishments and imposes on them the same duties and responsibilities as other private establishments. ${ }^{163}$ Thus, the law is neutral because it simply requires churches who object to the presence of guns on their property to follow the same steps as other private establishments. Here the problem for the church is getting past the neutrality and general applicability threshold. That is, the church can show a real burden to its religious belief and practice, but a court will never get to that question under the federal Constitution unless the church can show the law's lack of neutrality. ${ }^{164}$

Pro-gun churches will not be able to show any religious significance to their beliefs, while anti-gun churches will not be able to show that the laws are targeted at religion. The pro-gun churches will have to allege a "theology of gun possession" that may be manufactured only for the litigation. Courts would have to examine the theological basis of the pro-gun claim in order to determine whether or not the law burdens religion. ${ }^{165}$ Perhaps that is why courts easily glide over the burden issue to rule on other facets of the analysis, ${ }^{166}$ but ignoring the burden question in these gun cases is impossible. The Minnesota courts were seemingly persuaded by theological and religious claims of the plaintiffs. ${ }^{167}$ That may also be true for the Eleventh Circuit's decision. It created a distinction between "personal preferences" and "religious beliefs." 168 Apparently, the plaintiff churches in that case could not frame their arguments in terms religious enough to satisfy the court. ${ }^{169}$

162. See MINN. STAT. ANN. § 624.714(17)(a)-(c) (West 2009 \& Supp. 2015).

163. See id.; see also Edina, 745 N.W.2d at 201-02.

164. Emp't Div. v. Smith, 494 U.S. 872 (1990) (holding that neutral and generally applicable laws do not violate Free Exercise Clause).

165. See Edina, 745 N.W.2d at 207, 210-13.

166. See id. at 211 (citing Lemon v. Kurtzman, 403 U.S. 602 (1971)).

167. David Kopel might suggest that this was because of the Western church's pacifism and reliance on sentiment instead of reason. Kopel, Evolving Attitudes, supra note 20, at 1749-50.

168. See GeorgiaCarry.org, Inc. v. Georgia, 687 F.3d 1244, 1256-58 (11th Cir. 2012).

169. See id. at $1258-59$. 


\section{VII.THREE PERSISTENT RELIGIOUS LIBERTY PROBLEMS}

\section{A. The Non-Mainstream Religion Problem}

Although these cases are not likely to dominate free exercise dockets, they illustrate several ongoing free exercise issues. First, they show how difficult it is for courts to conceptualize religion claims, especially for non-mainstream religions. ${ }^{170}$ Scholars have long documented the difficulties non-mainstream religions have winning free exercise claims. ${ }^{171}$ Courts may more readily find religious burdens when a mainstream religion's claim does not challenge the conventional assumptions about "normal" religious belief and practices. ${ }^{172}$ These religions are so identified with majoritarian interests that it is difficult to see them as separate from them. ${ }^{173}$

Although most free exercise claimants lose, of the successful claimants, majority religions win more often than non-majority religions. ${ }^{174}$ Successful free exercise claims by minority religions are even less frequent. ${ }^{175}$ Mainstream Christian religions may find that

170. See Feldman, Religious Minorities, supra note 19, at 251-59.

171. See, e.g., Feldman, Christian America, supra note 121; Samuel J. Levine, Toward a Religious Minority Voice: A Look at Free Exercise Law Through a Religious Minority Perspective, 5 WM. \& MARY BILL RTS. J. 153, 160-62 (1996); Frank S. Ravitch, A Crack in the Wall: Pluralism, Prayer, and Pain in the Public Schools, in LAW AND RELIGION: A CRITICAL ANTHOLOGY, supra note 121, at 296, 296-303. But see Thomas C. Berg, Minority Religions and the Religion Clauses, 82 WASH. U. L.Q. 919, 922 (2004) ("[P]rotection ... of minority faiths should not be the sole criterion for Religion Clause cases."); Rosalie Berger Levinson, First Monday - The Dark Side of Federalism in the Nineties: Restricting Rights of Religious Minorities, 33 VAL. U. L. REV. 47 (1998); Suzanna Sherry, Religion and the Public Square: Making Democracy Safe for Religious Minorities, 47 DEPAUL L. REv. 499 (1998); David E. Steinberg, Religious Exemptions as Affirmative Action, 40 EMORY L.J. 77 (1991).

172. See Feldman, Religious Minorities, supra note 19, at 251-59.

173. See infra text accompanying notes 196-205. Nevertheless, unless a court uses a higher standard than currently used by the Supreme Court, the challengers may still lose because the laws are neutral and generally applicable. Compare Liberty Univ., Inc. v. Lew, 733 F.3d 72, 99 (4th Cir. 2013), cert. denied, 134 S. Ct. 683 (2013) (holding that the insurance requirement did not violate Free Exercise Clause because Affordable Care Act neutral and generally applicable), with Catholic Diocese of Beaumont v. Sebelius, 10 F. Supp. 3d 725 (E.D. Tex. 2014) (holding that the insurance requirement violated RFRA).

174. See James C. Brent, An Agent and Two Principals: U.S. Court of Appeals Responses to Employment Division, Department of Human Resources v. Smith and the Religious Freedom Restoration Act, 27 AM. POL. Q. 236, 250-51 (1999) (stating that 38.9\% of the winners were from mainstream Catholic and Protestant religions compared to $24.5 \%$ from non-mainstream religions).

175. Stephen Feldman argues that non-majority religions win a few free exercise claims but non-Christian minority religions rarely do. Feldman, Religious Minorities, supra note 19, 
legislatures are less likely to interfere with majoritarian practices, and if they do, judges are more receptive because they more readily identify with the claimants and their practices. ${ }^{176}$ Stephen Feldman describes how litigators for Jewish claimants in the early modern religion cases framed their claims to reflect majority, Protestant interests. ${ }^{17}$ Thus, even when minority religions win, they often do so because their interests align with majoritarian interests and values. ${ }^{178}$

This preference for mainstream claims can be seen in the different outcomes of the Edina and the GeorgiaCarry.org cases. In GeorgiaCarry.org, the court could find no justification for the claim that the law burdened any religious beliefs. ${ }^{179}$ The plaintiffs in Edina received a more sympathetic reception. The court simply asserted that there was no doubt that the law burdened the plaintiffs' religion, and the

at 251 (non-Christian religions never win at the Supreme Court level); see also Feldman, Christian America, supra note 121, at 273 n.5 (arguing that potential non-Christian religion free exercise victories are "ambiguous").

176. See Feldman, Religious Minorities, supra note 19, at 252 ("America is a predominantly Christian nation. It therefore is not unreasonable to suppose that Christians should receive preferential treatment at the hands of the Court. Christians probably are less likely to find that the exercise of their religion is burdened by laws in the first place. Because of the majoritarian process, lawmakers are less likely to adopt laws that place burdens on adherents of Christianity, the majority religion. If, however, Christians do find themselves in court defending the exercise of their religion, the judiciary is likely to be receptive to their claims. Primarily, this is because Christian judges should be more likely to be sympathetic to the plight of fellow Christians. The religious burden may appear more 'substantial,' or the governmental interests may seem less 'compelling' when they burden Christians than when they burden non-Christians. Therefore, mainstream Christians should prevail more often than non-Christians in free exercise cases." (quoting Brent, supra note 174, at 248)).

177. Id. at 249.

178. See, e.g., Wisconsin v. Yoder, 406 U.S. 205, 221, 225, 235 (1972) (noting approvingly that the Amish fell within a long tradition of self-reliance); see also Linda C. McClain, Against Agnosticism: Why the Liberal State Isn't Just One (Authority) Among the Many, 93 B.U. L. REV. 1319, 1337 (2013) ("[T] American values ...."). Derek Bell pointed out a similar dynamic in school desegregation and civil rights cases. See Derrick A. Bell, Jr., Brown v. Board of Education and the InterestConvergence Dilemma, 93 HARV. L. REV. 518 (1980). This dynamic plays itself out in civil rights cases, too. See id. at 524-25 (suggesting that African-American plaintiffs win when their interests coincide with the white majority); see also Derrick A. Bell, Jr., Serving Two Masters: Integration Ideals and Client Interests in School Desegregation Litigation, 85 YALE L.J. 470 (1976) (arguing that mainstream interests of lawyers took precedence over interests of community).

179. GeorgiaCarry.org, Inc. v. Georgia, 687 F.3d 1244, 1258 (11th Cir. 2012). 
state conceded the sincerity of the belief. ${ }^{180}$ It is not self-evident, however, what the burden actually was.

The plaintiffs objected to two requirements: that they put up a sign with state-mandated wording to put people on notice of their no-gun policy and that they allow permit holders to have their guns on church parking lots. ${ }^{181}$ The churches noted their commitment to peace and nonviolence, but there was nothing in either regulation that interfered with these beliefs. ${ }^{182}$ Indeed, there was little in the law that interfered with their practices either. ${ }^{183}$ The churches' prohibition on weapons continued unabated whether they were categorically exempt or if they posted notice. ${ }^{184}$ Minnesota's law accommodated the rights of private establishments, a category that surely includes places of worship. ${ }^{185}$

Declaring that guns were forbidden was an accurate statement of their religious beliefs, ${ }^{186}$ and by doing so, the law allowed them to continue their practices. Similarly, the parking lot provision could only plausibly constitute a burden in those few times when the lot was used for religious practice. ${ }^{187}$ Even then, the guns would remain in vehicles and not be on any participant. Moreover, as the court noted, public, onand off-street parking was readily available. ${ }^{188}$ It would not be much more difficult for a person to gain access to a weapon in nearby onstreet parking as it would be in the church parking lot.

The ease with which the court found this burden is consistent with the way courts treat claims by mainstream religions. ${ }^{199}$ Non-violence seems like a "natural" religious position. ${ }^{190}$ The presence of weapons, even in locked cars, suggests the possibility of violence. Therefore, it 2008).

180. Edina Cmty. Lutheran Church v. State, 745 N.W.2d 194, 203-208 (Minn. Ct. App.

181. Id. at 202.

182. See id. 203.

183. Id. at 204-08.

184. See id.

185. MinN. STAT. ANN. $\$ 624.714(17)(b)(4)(d)$ (West $2009 \&$ Supp. 2015). Churches own an estimated $\$ 300$ billion to $\$ 500$ billion in untaxed church property. Jeff Schweitzer, The Church of America, HUFFINGTON POST (Oct. 10, 2011, 3:49 PM), http://www.huffingtonp ost.com/jeff-schweitzer/robert-jeffress-romney_b_1002753.html, (last updated Dec. 11, 2011, 5:12 AM), archived at $\mathrm{http}: / /$ perma.cc/256E-4GM5.

186. See Edina, 745 N.W.2d at 200.

187. See id. at 206-07.

188. Id. at 209.

189. See supra notes $\mathbf{1 7 4 - 7 8}$ and accompanying text.

190. Kopel, Evolving Attitudes, supra note 20 (claiming that Western Christian churches moved toward pacifism during the twentieth century). 
was "obvious" that the law burdened religion. The GeorgiaCarry.org plaintiffs had to fight this perception. They wanted their parishioners to be armed for their and the congregation's protection, ${ }^{191}$ but this runs directly counter to the "natural" perception that religion and places of worship are refuges from violence. ${ }^{192}$ Yet places of worship are victimized by violence. ${ }^{193}$ Most faiths have developed theological justifications for the use of violence in certain circumstances. ${ }^{194}$ Thus, far from being in the mainstream, pacifism may be the exception for American religions. ${ }^{195}$

Discerning a burden is a difficult task, ${ }^{196}$ but asking courts to find a burden on religion without inquiring into the religious basis for the

191. GeorgiaCarry.org, Inc. v. Georgia, 687 F.3d at 1249 n.8.

192. See Edina, 745 N.W.2d at $199-200$.

193. See, e.g., Whitman, supra note 12, at 1988-89; Shaila Dewan, Hate for Liberals and Gay People Drove Gunman, Police Say, N.Y. TIMES, July 29, 2008, at A15; Steven Yaccino, Michael Schwirtz \& Marc Santora, Gunman Kills 6 at Sikh Temple Near Milwaukee, N.Y. TIMES, Aug. 6, 2012, at A1; Hayley Mason \& Nancy Amons, Woman Dies From Injuries in Cookeville Church Shooting, WSMV (Feb. 2, 2014, 11:48 AM), http://www.wsmv.com/story/24 612934/fatal-shooting-inside-cookeville-church, (last updated Mar. 2, 2014, 11:53 AM), archived at $\mathrm{http}: / /$ perma.cc/F3JS-KZ5E. Indeed, the incidents near Milwaukee and Knoxville were cited by the federal government in 2013 when it released a guide to help houses of worship deal with active shooters. See FEMA, GUIDE FOR DEVELOPING High-QUALITY EMERGENCY OPERATIONS PLANS FOR HOUSES OF WORSHIP 23 (2013), available at http://www.fema.gov/media-library/assets/documents/33007, archived at http://perma.cc/8VFS$6 \mathrm{~W} 2 \mathrm{U}$. One of its recommendations is to fight back. Id. at 30. ("If neither running nor hiding is a safe option, as a last resort, when confronted by the shooter, adults in immediate danger should consider trying to disrupt or incapacitate the shooter by using aggressive force and items in their environment, such as fire extinguishers or chairs."). The guide goes on to suggest that houses of worship should come up with "policies on the control and presence of weapons, as permitted by law." Id. (emphasis added).

194. See generally David B. Kopel, The Catholic Second Amendment, 29 HAMLINE L. REV. 519 (2006) (addressing, among other topics, the catechism and canon law on selfdefense and just war); David B. Kopel, The Torah and Self-Defense, 109 PENN ST. L. REV. 17 (2004) (discussing Jewish "teachings on the right to ... defend oneself and others").

195. See, e.g., Kopel, Religious Roots, supra note 20 (religious sentiment at the founding saw self-defense as a sacred duty). This does not contradict the claim that non-mainstream religions find it difficult to win free exercise cases. See Feldman, Christian America, supra note 121. This is not a theological or analytical process. That is, courts do not investigate the theological or historical background of the claims in front of them. Rather, they operate based on social and cultural assumptions about what is "normal" or "natural." That Western religions might justify the use of force is not at the forefront of the judicial mind. Rather, the non-violence claims fall within a contemporary narrative of peaceful religion while the possession of weapons falls outside that narrative.

196. See Mark Tushnet, Heller and the Perils of Compromise, 13 LEWIS \& ClaRK L. REV. 419, 425 \& n.28 (2009) (comparing part of the analysis in Heller to discerning a burden in free exercise cases). 
practice may be asking too much of them. Judges are subject to the same cognitive, cultural and social biases as everyone else. ${ }^{197}$ "Religion" powerfully frames the issue and activates deep cognitive processes. As Professor Krotoszynski notes,

The very notion of "religion" triggers deep-seated, largely unconscious cultural associations and understandings. To ask someone to characterize a particular group as a "religion" requires her to draw a material equivalency between the beliefs of the group in question and her own beliefs; if the equivalency seems unwarranted because of the bizarre nature of the group's theology, she might well prove unwilling to accept that the other group is a legitimate "religion" in the same way as her own. "The attitude that most affects social and political behavior is prejudice against people who are different."198

When faced with ideas or behavior at odds with our own, cognitive dissonance results. ${ }^{199}$ We reduce that dissonance by removing the disagreeable idea or behavior. ${ }^{200}$ Because there is no legal definition of religion for free exercise purposes, a judge must subconsciously evaluate the authenticity of the claim and the claimant. ${ }^{201}$ An individual confronted with a religious belief that she views as unusual or bizarre may cause her to discount that belief and reaffirm her own. ${ }^{202}$ Judges

197. See Gregory C. Sisk, Michael Heise \& Andrew P. Morriss, Searching for the Soul of Judicial Decisionmaking: An Empirical Study of Religious Freedom Decisions, 65 OHIO ST. L.J. 491 (2004) (noting that the religion of the claimant, the judge, and the community are the most salient features of judicial decision making).

198. Ronald J. Krotoszynski, Jr., If Judges Were Angels: Religious Equality, Free Exercise, and the (Underappreciated) Merits of Smith, 102 NW. U. L. REV. 1189, 1235 (2008) (footnotes omitted) (quoting JOSEPH F. BYRNES, THE PSYCHOLOGY OF RELIGION 151 (1984)).

199. See generally PAUl BREST \& Linda Hamilton KRIEger, PROBlem SOlVING, DECISION MAKING, AND PROFESSIONAL JUdGMENT: A GUIDE FOR LAWYERS AND POLICYMAKERS 366 (2010) (summarizing cognitive dissonance theory with references).

200. Id.

201. See, e.g., Ira C. Lupu, Where Rights Begin: The Problem of Burdens on the Free Exercise of Religion, 102 HARV. L. REV. 933, 954 (1989) ("[T] he questioning of sincerity may operate invisibly and subconsciously against unknown or unpopular religions. The more unusual a claimant's religion, the easier it will be for decisionmakers to conclude, on the basis of an unarticulated view that 'no one could really believe this,' that the claimant's beliefs are not sincerely held."); Marshall, supra note 66, at 311 ("Minority belief systems - not majority belief systems - will bear the brunt of the definition and the sincerity inquiries.").

202. See Krotoszynski, supra note 198 , at 1235 ; see also Stephen M. Feldman, Empiricism, Religion, and Judicial Decision-Making, 15 WM. \& MARY BILL RTS. J. 43, 47 (2006) ("When tangible conflicts between social groups arise, the cohesion within each 
who must decide if a neutral law burdens an "unusual or bizarre" belief will likely employ cognitively similar tactics. ${ }^{203}$ The decisions of the federal courts may reflect this process of dividing claims into acceptable and unacceptable religions. ${ }^{204}$ The result is that non-mainstream religions bring more and lose more free exercise cases than mainstream religions. ${ }^{205}$

The very nature of religious claims makes them difficult to translate into contemporary legal categories. ${ }^{206}$ The translation process sanitizes them or leaves them impossible to understand by a "rational" and

respective group and the salience of the division between groups are both likely to increase."); Ramzi Kassem, Implausible Realities: Iqbal's Entrenchment of Majority Group Skepticism Towards Discrimination Claims, 114 PENN ST. L. REV. 1443, 1461-62 (2010) (stating that the federal bench is "remarkably homogenous" compared to general population).

203. Krotoszynski, supra note 198, at 1193 (“[P]ervasive social hostility to religions that maintain nontraditional belief systems leads judges to discount the relative importance of religiously motivated behavior that conflicts with a neutral law of general applicability; courts either find that the governmental policy in question does not "burden" the religion (or burdens it only indirectly) or, alternatively, find that the legislative goals advanced by the law actually advance a compelling interest in a narrowly tailored way."). "The decisions of the federal courts reflect the same sort of effort to classify religion into acceptable denominations verses unacceptable cults." Id. at 1241.

204. See id. at 1240-41.

205. Id. at $1244-45$ ("The pattern is reasonably clear: minority religious groups bring far more cases than do more traditional majority religious groups. But even though minority religionists bring far more cases, their success rate in the federal courts is much lower. Minority religionists bring and lose more cases; majority religionists bring fewer cases and win a larger percentage of them." (footnotes omitted)); Marshall, supra note 66, at 311 (arguing that a negative outcome is more likely "when the religion is bizarre, relative to the cultural norm," or "when the belief in question is, by cultural norms, incredulous"); Gregory C. Sisk \& Michael Heise, Muslims and Religious Liberty in the Era of 9/11: Empirical Evidence from the Federal Courts, 98 IOWA L. REv. 231, 235 (2012) (noting that Muslims faced substantial disadvantage in religious liberty cases compared to other religious groups). But see Gregory C. Sisk, How Traditional and Minority Religions Fare in the Courts: Empirical Evidence from Religious Liberty Cases, 76 U. COLO. L. REv. 1021, 1036 (2005) (stating that the hypothesis that minority or unconventional religions are at a disadvantage in court is not supported by study's data).

206. See, e.g., Suzanna Sherry, Enlightening the Religion Clauses, 7 J. CONTEMP. LEGAL ISSUES 473, 478 (1996) ("For the faithful, the ultimate authority and source of truth is extrahuman, and evidence can - and in some religious traditions, must - be entirely personal to the individual; for the reasonable, both the source and the evidence for the truth lie in common human observation, experience, and reasoning. To have faith is to affirm a transcendent reality, different from that observed by nonbelievers."); see also Donald L. Beschle, Does a Broad Free Exercise Right Require a Narrow Definition of "Religion"?, 39 HASTINGS CONST. L.Q. 357 (2011) (arguing that modern religious diversity necessitates an expansive definition of religion). 
"objective" analysis. ${ }^{207}$ In a world that has long since declared God's death, claims of religious truth and obligation fail to resonate. ${ }^{208}$ As Professor Paulsen argues, true religious claims are different from other obligations, however deeply felt.

The nature of religious obligation is intrinsically different from philosophical or moral belief systems that involve no conception of a transcendent Creator, God. The believer understands himself to be under the superior authority of God. The ethical humanist, secularist, or atheist does not; he does not believe in God. Rather, he is subject to the moral commands he discerns for himself. (In a very real sense, the atheist is "God" for himself, the only ultimate authority over his own conscience. He really is, in Smith's words, "a law unto himself.") 209

Religion not only assumes a command superior to the state's, it also plays a central role in one's identity. ${ }^{210}$ Perhaps, then, the only burdens the Free Exercise Clause should care about are those that leave the individual with a stark choice: violate the law or violate your religion. Courts should only protect those infringements that go to the heart of one's religious practice and identity: where following one's secular obligations is not merely inconvenient but fundamentally inconsistent with one's religious principles. Preventing Sikh children from taking their kirpan into schools is such a choice. ${ }^{211}$ It is not clear that preventing Baptists from taking their guns into their church service is

207. See Michael Stokes Paulsen, The Priority of God: A Theory of Religious Liberty, 39 PEPP. L. REV. 1159 (2013).

208. See Michael W. McConnell, "God is Dead and We Have Killed Him!": Freedom of Religion in the Post-Modern Age, 1993 BYU L. REV. 163; Paulsen, supra note 207.

209. Paulsen, supra note 207, at 1203 (quoting Emp't Div. v. Smith, 494 U.S. 872, 885 (1990)). But see Christopher L. Eisgruber \& LAWRENCE G. SAGER, Religious FREEDOM AND THE CONSTITUTION (2007).

210. Abner S. Greene, Constitutional Reductionism, Rawls, and the Religion Clauses, 72 FORDHAM L. REV. 2089, 2091 (2004) ("Religion, on my argument, is different because it is based in an extrahuman source of normative authority."). But see HAMILTON, supra note 109 (accommodating religion does not create more good than harm); LEITER, supra note 90, at 32-36 (suggesting that there is no difference between identity and obligation); Micah Schwartzman, What If Religion Is Not Special?, 79 U. CHI. L. REV. 1351, 1401 (2012) ("[R]eligion is not morally distinctive ....").

211. "A religious dictate ... is more than a question of identity; it is a duty." Michael W. McConnell, Why Protect Religious Freedom?, 123 YALE L.J. 770, 799-800 (2013) [hereinafter McConnell, Why Protect] (reviewing LEITER, supra note 90) (discussing Brian Leiter's comparison of a Sikh child's religious obligation to carry the kirpan and a rural child's conscientious desire to carry a pocket knife); see also LEITER, supra note 90, at 1-3. 
the same thing. ${ }^{212}$ Yet such a harsh standard would involve the courts even more deeply in purely religious questions, ${ }^{213}$ carve out a huge space for government to occupy in the lives of citizens, ${ }^{214}$ and ultimately devalue the role of religious belief in an individual's life. ${ }^{215}$

\section{B. The Exemption Problem}

Second, these cases are part of the larger debate about how easy it should be to get religious exemptions from general laws. ${ }^{216}$ Too easy

212. See, e.g., LEITER, supra note $90,1-3$ (comparing a rural boy who receives a pocket knife as a rite of passage and the Sikh boy who carries the kirpan as part of his religious identity).

213. See Smith, 494 U.S. at 886-87 (stating that courts must not determine the importance or the plausibility of religious claims); Hernandez v. Comm'r, 490 U.S. 680, 699 (1989) (noting that centrality of religious belief not for judiciary to decide); Thomas $v$. Review Bd., 450 U.S. 707, 716 (1981) ("Courts are not arbiters of scriptural interpretation.").

214. Hamilton notes the increasing libertarianism of modern day free exercise jurisprudence. See HAmilton, supra note 109, at 206. Some scholars have argued that modern Free Exercise Clause jurisprudence is about protection of individual autonomy. See, e.g., Steven H. Shiffrin, The Pluralistic Foundations of the Religion Clauses, 90 CORNELL L. REV. 9, 93 (2004). Others claim that this modern focus is misplaced and that equality of religion (or conscience) is the correct focus of the Free Exercise Clause. See, e.g., Bret Boyce, Equality and the Free Exercise of Religion, 57 CLEV. ST. L. REV. 493, 552 (2009) ("The free exercise of religion requires equal and impartial treatment of all regardless of their beliefs, not a patchwork of special privileges, favors, and exemptions."); Christopher L. Eisgruber \& Lawrence G. Sager, The Vulnerability of Conscience: The Constitutional Basis for Protecting Religious Conduct, 61 U. CHI. L. REV. 1245 (1994); William P. Marshall, What is the Matter with Equality?: An Assessment of the Equal Treatment of Religion and Nonreligion in First Amendment Jurisprudence, 75 IND. L.J. 193, 194 (2000) (stating that equality serves as a "center of gravity, assuring that the constitutional status of religion does not veer too far in any one direction").

215. See Laycock, Religious Exemption, supra note 69, at 176 (noting that without exemptions the right to believe is "hollow").

216. See, e.g., Abner S. Greene, Against Obligation: The Multiple Sources OF AUTHORITY IN A LIBERAL DEMOCRACY 3-4 (2012) (suggesting that broad exemptions are necessary to accommodate plural authorities); Abner S. Greene, Civil Society and Multiple Repositories of Power, 75 CHI.-KENT L. REV. 477 (1999) (explaining that the pluralist understanding of authority is more compatible with constitutional order). Compare McConnell, Why Protect, supra note 211 (arguing for constitutional religious exemptions on originalist grounds), with Philip Hamburger, A Constitutional Right of Religious Exemption: An Historical Perspective, 60 GEO. WASH. L. REV. 915, 916-17 (1992) (arguing against religious exemptions on originalist grounds), and Schwartzman, supra note 210, at 1406 (stating that there is no consensus among originalists on the issue of free exercise exemptions). But see Frederick Mark Gedicks, An Unfirm Foundation: The Regrettable Indefensibility of Religious Exemptions, 20 U. ARK. LITTLE ROCK L.J. 555, 574 (1998) (concluding there is no plausible explanation of why only religious believers are constitutionally entitled to exemptions from general laws); McClain, supra note 178 
acceptance of religious claims would cause unnecessary expense and enforcement difficulties even, perhaps, chaos. ${ }^{217}$ Too stingy an approach and religious freedom becomes an empty promise. ${ }^{218}$

Two leading religion clause scholars, Professors Marci Hamilton and Douglas Laycock, recently engaged in a sometimes vitriolic debate on this issue. ${ }^{219}$ Hamilton argues that we should be wary of granting religious exemptions from general laws because religions have caused significant social harm. ${ }^{220}$ Judicially crafted exemptions through the Free Exercise Clause allow courts, which are not equipped to deal with weighing of complex social and cultural factors, to pick and choose social and political winners and losers. ${ }^{221}$ Exemptions should only be given by legislatures on a case-by-case basis when no significant harm to others will result.

Exempting religious conduct from neutral, general laws must be (1) duly enacted by a legislature, not decreed by a court; (2) must be debated under the harsh glare of public scrutiny; and (3) must be consistent with the larger public good. Where the burden on religious conduct can be lifted by the legislature with only de minimis harm to the public, there is good reason to accommodate the religious conduct. ${ }^{222}$

Laycock critiques this position in a no-holds-barred book review. ${ }^{223}$ $\mathrm{He}$ calls it a "dreadful book" and most of it a "poorly executed rant-

(suggesting that broad exemptions may undermine state's interest in equality and in protecting children).

217. See Smith, 494 U.S. at 888 (suggesting that broad exemptions would be "courting anarchy"); LEITER, supra note 90 , at 94 (noting that broad exemptions could be something like "anarchy"); see also, e.g., Burwell v. Hobby Lobby Stores, Inc., 134 S. Ct. 2751 (2014) (involving a for-profit company that objected to four of twenty contraceptive methods required to be included in health insurance plan).

218. Laycock, Religious Exemption, supra note 69, at 176 ("Regulatory exemptions are an essential part of meaningful religious liberty. The right to believe a religion is hollow without the right to practice the religion; it leaves committed believers subject to persecution for exercising their religion.").

219. Marci A. Hamilton, A Response to Professor Laycock, 105 MiCH. L. REv. 1189 (2007); Douglas Laycock, God vs. the Gavel: A Brief Rejoinder, 105 MICH. L. REV. 1545 (2007); Douglas Laycock, A Syllabus of Errors, 105 MICH. L. REV. 1169 (2007) [hereinafter Laycock, Syllabus of Errors] (reviewing HAMILTON, supra note 109).

220. HAMILTON, supra note 109 , at 274 ("[R]eligious entities can be responsible for lethal medical neglect of children, childhood sexual abuse, [and] the takeover of neighboring property owner's rights under the zoning laws, ... among other conduct.").

221. See id. at 275 .

222. Id.

223. See Laycock, Syllabus of Errors, supra note 219. 
disorganized, self-contradictory, and riddled with errors."224 Laycock charges that Hamilton accuses courts for being overly sensitive to religious claims while ignoring the same thing in legislatures. ${ }^{225}$ To Laycock, judicially crafted exemptions can protect religious freedom. ${ }^{226}$ Judges are removed from politics and, thus, less likely to be swayed by political influence. ${ }^{227}$ This distance also allows judges to more carefully sift facts and evaluate claims. ${ }^{228}$

This debate about the proper institution to grant exemptions is only a symptom of their more fundamental disagreement. Hamilton fears religion's influence in modern society, while Laycock is agnostic. ${ }^{229}$ Hamilton's calculus leads her to the conclusion that broad religious exemptions cause more harm than good. ${ }^{230}$ No group, religious or not,

224. Id. at 1169.

225. Id. at 1173 ("Legislators have exempted harmful religious behavior that no judge would ever exempt under a generally applicable standard - most notably, parents refusing to provide medical care for their children.").

226. See id. at 1177 ("Hamilton's examples show that judges are less likely to grant foolish exemptions that result in serious harm. Judges sometimes are willing to protect unpopular minorities, but legislators hardly ever; legislators cannot afford to protect any group that is seriously unpopular with voters."); see also Michael J. Perry, Freedom of Religion in the United States: Fin de Siecle Sketches, 75 IND. L.J. 295, 306 (2000) ("The fundamental question here, I think, is twofold: How skeptical of ordinary politics, how distrustful, ought we to be when it comes to the protection of religious minorities? And how vigorously ought we to want the judiciary to protect, against discrimination, religious minorities and their religious practice? My answer to the first question: very skeptically. My answer to the second: very vigorously.").

227. See Laycock, Syllabus of Errors, supra note 219, at 117-77. He uses the federal courts as examples, however, and does not explain how this insulation would operate in jurisdictions that elect their judges. See id. Recent state judicial elections show that decisions with religious and cultural overtones can have serious repercussions for elected judges. For example, three Iowa Supreme Court justices lost their retention elections after an aggressive campaign against their support of a ruling striking down Iowa's ban on same-sex marriages. Grant Schulte, Iowans Dismiss Three Justices, DES MOINES REG. (Nov. 3, 2010), http://www. desmoinesregister.com/article/20101103/NEWS09/11030390/lowans-dismiss-three-justices?ncl ick_check=1, archived at http://perma.cc/2X2W-SX4X.

228. Laycock, Syllabus of Errors, supra note 159, at 1175-77.

229. Compare HAMILTON, supra note 109, at 3 ("The purpose of this book is to persuade Americans to take off the rose-colored glasses and to come to terms with the necessity of making religious individuals and institutions accountable to the law so that they do not harm others."), with Douglas Laycock, Religious Liberty As Liberty, 7 J. CONTEMP. LEGAL IsSUES 313, 314, 353 (1996) [hereinafter Laycock, Religious Liberty] ("Religious liberty does not view religion as a good thing to be promoted, nor as a dangerous force to be contained. But people who view religion in each of these ways struggle to capture the Religion Clauses for their side.").

230. HAMILTON, supra note 109 , at 8 (stating that exemptions should only be granted when "immunizing religious conduct is consistent with public welfare, health, and safety"). 
should be allowed to cause harm to the broader society. ${ }^{231}$ Laycock reaches a different conclusion. ${ }^{232}$ Protecting religious freedom is important and necessary because (1) the Constitution says we should; (2) religion is a deeply held, fundamental belief for many people; and (3) without broad judicially crafted exemptions, religion can become a divisive force in ordinary politics. ${ }^{233}$

If all it takes to gain an exemption is to wrap religion around a personal or political position, then everyone will be a "law unto themselves." ${ }^{234}$ Without some limiting principle to filter claims, ${ }^{235}$ the Free Exercise Clause will either swallow up the rest of the Constitution or be emptied of content. ${ }^{236}$ Hamilton and Laycock demonstrate, however, that discerning the correct principle will not be easy.

Id. at 304 ("[This] approach ... is consistent with the high ideal of republicanism - to yield the greatest good possible for the people."). She is not alone in her skepticism. See, e.g., Gedicks, supra note 216, at 574 ("There no longer exists a plausible explanation of why religious believers - and only believers - are constitutionally entitled to be excused from complying with otherwise legitimate laws that burden practices motivated by moral belief."); Sherry, supra note 206, at 495 ("[T] for preferential treatment, nor is it required to treat alternative epistemologies as favorably as Enlightenment rationality.... To do otherwise is for the government to accept as true the claims of particular religious believers - a course of action that is dangerous to government and religion alike....").

231. See HAMILTON, supra note 109, at 303 ("The rule of law is diminished when individuals may use their personal beliefs to avoid the law and to harm others.").

232. See Laycock, Religious Liberty, supra note 229, at 319 ("[R]eligion is to be left as wholly to private choice and private commitment as anything can be.").

233. Id. at 317.

234. See Emp't Div. v. Smith, 494 U.S. 872, 879 (1990) (“'Laws,' we said, 'are made for the government of actions, and while they cannot interfere with mere religious belief and opinions, they may with practices. ... Can a man excuse his practices to the contrary because of his religious belief? To permit this would be to make the professed doctrines of religious belief superior to the law of the land, and in effect to permit every citizen to become a law unto himself."' (alteration in original) (quoting Reynolds v. United States, 98 U.S. 145, 166$67(1878)))$.

235. See, e.g., LEITER, supra note 90, at 94 (arguing that there is no principled way to distinguish religious exemptions from other claims of conscience); Angela C. Carmella, Responsible Freedom Under The Religion Clauses: Exemptions, Legal Pluralism, and the Common Good, 110 W. VA. L. REV. 403, 409 (2007) (arguing that the question of exemptions requires normative judgment about their contribution to the common good).

236. See, e.g., LEITER, supra note 90, at 94-98 (arguing that an exemption regime either would constitutionalize civil disobedience or would lead to unfair exclusions); Carmella, supra note 235 , at 409 (stating that an alternative to normative judgment would be to create "absolute religious freedom or to impose only the state's legal norms"). 


\section{The Neutrality Problem}

Third, the gun cases relate to what it means to be "neutral" as to religion. Courts use neutrality as the talisman of religion clause jurisprudence without explaining what being neutral really means. ${ }^{237}$ Douglas Laycock has argued that instead of a single concept called "neutrality," there are three different ways that laws can be neutral as to religion. ${ }^{238} \mathrm{He}$ distinguishes between formal neutrality, substantive neutrality, and disaggregated neutrality. ${ }^{239}$ Formal neutrality requires the government to use neutral categories. ${ }^{240}$ Substantive neutrality requires the government to use neutral incentives. ${ }^{241}$ Laycock uses the example of a ban on children drinking alcohol. ${ }^{242}$ The ban is formally neutral because it does not use religion as a defining category. ${ }^{243}$ Like the statutes in the opt-out jurisdictions, it applies to everyone regardless

237. See, e.g., Bd. of Educ. v. Grumet, 512 U.S. 687, 705 (1994); Smith, 494 U.S. 872 (laws must be neutral and generally applicable); Corp. of Presiding Bishop of the Church of Jesus Christ of Latter-Day Saints v. Amos, 483 U.S. 327, 334 (1987); Comm. for Pub. Educ. \& Religious Liberty v. Nyquist, 413 U.S. 756, 792 (1973); Walz v. Tax Comm'n, 397 U.S. 664, 669 (1970); see also Douglas Laycock, Substantive Neutrality Revisited, 110 W. VA. L. REV. 51, 56 (2007) [hereinafter Laycock, Substantive Neutrality] (stating that the Supreme Court has been "notoriously inconsistent" with neutrality); R. George Wright, Can We Make Sense of "Neutrality" in the Religion Clause Cases?: Seven Rescue Attempts and a Viable Alternative, 65 SMU L. REV. 877, 878-79 nn.1-2 (2012) (comprehensive listing of federal courts' use of neutrality).

238. Douglas Laycock, Formal, Substantive, and Disaggregated Neutrality Toward Religion, 39 DEPAUL L. REV. 993, 999-1011 (1990) [hereinafter Laycock, Neutrality Toward Religion]; see Laycock, Substantive Neutrality, supra note 237, at 52; see also Andrew Koppelman, And I Don't Care What It Is: Religious Neutrality in American Law, 39 PEPP. L. REV. 1115 (2013) (arguing that neutrality is a master concept that operates in slightly different ways in different contexts.). But see Chad Flanders, Can We Please Stop Talking About Neutrality? Koppelman Between Scalia and Rawls, 39 PEPP. L. REV. 1139, 1147 (2013) ("We are better off, I think, giving up on neutrality as a term of art and simply arguing directly in terms of religion's distinct value: we protect religion not because we are being neutral, but because of the value of religion as such.").

239. Laycock, Neutrality Toward Religion, supra note 238, at 999-1011.

240. Laycock, Substantive Neutrality, supra note 237, at 54 ("Formal neutrality requires neutral categories. A law is formally neutral if it does not use religion as a category-if religious and secular examples of the same phenomenon are treated exactly the same.").

241. Id. at 54-55 ("Substantive neutrality requires neutral incentives. A law is substantively neutral if it neither 'encourages [n] discourages religious belief or disbelief, practice or nonpractice, observance or nonobservance." (alteration in original) (quoting Laycock, Neutrality Toward Religion, supra note 238, at 1001)).

242. Id. at 55 .

243. Id. 
of religious or secular status. ${ }^{244}$ But it would be proper for states to make exceptions for such practices (or, at least, look the other way):

[A]n exception that permits children to take communion wine is substantively neutral. Exempting communion wine from the ban on under-age consumption of alcohol is extraordinarily unlikely to induce anyone to become a Christian, to join a denomination that uses real wine in its communion service, or to attend communion services more often - unless that person already desired to do these things but had been deterred by the threat of government-imposed penalties. Consuming communion wine is a desirable activity only to those who already believe in the religious teaching that gives meaning to the act. Forbidding children to take communion wine, or criminally punishing their parents and the priest who gives them the sacrament, powerfully discourages an act of worship. But exemption does not encourage any child to take communion, or any parent to take his child to a communion service, who is not already religiously motivated do so. An exemption does not change anyone's religious incentives; criminalization changes those incentives profoundly. ${ }^{245}$

Categorical jurisdictions explicitly use religion to set houses of worship apart from most private property owners. ${ }^{246}$ Apparently, houses of worship are thought to be like other public or government buildings. If so, then these laws are formally neutral because "religious and secular examples of the same phenomenon" are treated alike. ${ }^{247}$ On the surface, that appears true. On closer inspection, however, this exclusion seems to flow from assumptions about the naturalness or reasonableness of religious claims. ${ }^{248}$

At the same time, opt-out jurisdictions are substantively neutral because they allow property owners, including houses of worship, to exclude guns from their property upon compliance with the statutory

244. See Laycock, Substantive Neutrality, supra note 237, at 55 ("[F]orbidding children to take communion wine is formally neutral. Children cannot consume alcoholic beverages in any amount for any purpose. Religion is not a category in the formulation or application of this rule; alcohol is forbidden to children whether for religious purposes or secular purposes."); supra note 14.

245. Laycock, Substantive Neutrality, supra note 237, at 55 (emphasis added).

246. E.g., GA. CODE ANN. § 16-11-127(b) (2011 \& Supp. 2013).

247. See Laycock, Substantive Neutrality, supra note 237, at 54.

248. See supra notes $189-95$ and accompanying text. 
requirements. ${ }^{249}$ Here the law is formally neutral on its face but substantively neutral in its application. Under this categorization, however, the cases should have been analyzed in a different way. The substantively neutral restrictions of Minnesota's opt-out law was found to burden religion and was subjected to a strict scrutiny analysis because it seemed that the religious claim was more reasonable. ${ }^{250}$ Georgia's categorical ban lacked formal neutrality (and for that matter, substantive neutrality as well) but was not found to even burden religion. ${ }^{251}$ In Laycock's terms, the categorical ban served to "discourage[] religious ... practice ... [or] observance."252

Perhaps searching for neutrality is a fool's errand. As Steven Smith noted,

[T]he quest for neutrality, despite its understandable appeal and the tenacity with which it has been pursued, is an attempt to grasp at an illusion. Upon reflection, this failure should not be surprising. The impossibility of a truly "neutral" theory of religious freedom is analogous to the impossibility, recognized by modern philosophers, of finding some outside Archimedean point ... from which to look down on and describe reality. Descriptions of reality are always undertaken from a point within reality. In the same way, theories of religious freedom are always offered from the viewpoint of one of the competing positions that generate the need for such a theory; there is no neutral vantage point that can permit the theorist or judge to transcend these competing positions. ${ }^{253}$

The gun cases show how difficult it is to find a "neutral" vantage point from which to view religion cases. The result is that courts will avoid the actual right at issue and rely on background assumptions about religion and neutrality. ${ }^{254}$ Perhaps the very nature of religious

249. See supra note 14.

250. See Edina Cmty. Lutheran Church v. Minnesota, 745 N.W.2d 194, 203-211 (Minn. Ct. App. 2008).

251. See GeorgiaCarry.org, Inc. v. Georgia, 687 F.3d, 1244, 1255-56 (11th Cir. 2012). The court seemed to conflate the burden question with the question about the neutrality of the law.

252. Laycock, Neutrality Toward Religion, supra note 238, at 1001, quoted in Laycock, Substantive Neutrality, supra note 237, at 54-55.

253. STEVEN D. SMITH, FOREORDAINED FAILURE: THE QUEST FOR A CONSTITUTIONAL PRINCIPLE OF RELIGIOUS FREEDOM 96-97 (1995).

254. See supra notes $189-95$ and accompanying text; see also Frank S. Ravitch, Rights and the Religion Clauses, 3 DUKE J. CONST. L. \& PUB. POL'Y 91 (2008) (arguing that the 
claims makes them difficult, if not impossible, to translate into legal categories. ${ }^{255}$ They are either impossible to understand by a "rational" and "objective" analysis or sanitized, tamed, or corrupted. ${ }^{256}$ Moreover, particularistic religious claims for exemptions do not co-exist well in an increasingly diverse and non-religious country. ${ }^{257}$ Finding a neutral vantage point in such difficult terrain seems unlikely. ${ }^{258}$

\section{CONCLUSION: WHAT'S FREE EXERCISE FOR?}

These three issues share a common core: what is the purpose of the Free Exercise Clause, what functions does it serve, historically and today, and what should it protect. Modern law focuses on protecting the autonomy of the individual believer. ${ }^{259}$ The Free Exercise Clause, perhaps like the Free Speech Clause, allows the individual to forge a personal identity free from government compulsion. ${ }^{260}$ Under this

Supreme Court's shift to formal neutrality has shifted religion clause doctrine from protecting minority religions to preserving majority religions' political and social dominance). But see Sisk, supra note 205, at 1036 (stating that majority religion claimants have no advantage in religion clause cases).

255. See, e.g., Abner S. Greene, Is Religion Special? A Rejoinder to Scott Idleman, 1994 U. ILL. L. REV. 535, 540 [hereinafter Greene, Is Religion Special?] ("[R]eligion selfconsciously revels in the unsensible, whereas science and other sources from which people make arguments at least purport to rely solely on the observable, on what we share as humans.").

256. See supra notes 206-09 and accompanying text.

257. See THE PEW Forum ON RELIGION AND PUB. LIFE, U.S. RELIGIOUS LANDSCAPE SURVEY 1 (2008), available at $\mathrm{http}: / /$ religions.pewforum.org/pdf/report-religious-landscape-st udy-full.pdf, archived at http://perma.cc/UY8Z-NEJ5.

258. See, e.g., Alan E. Brownstein, Interpreting the Religion Clauses in Terms of Liberty, Equality, and Free Speech Values - A Critical Analysis of "Neutrality Theory" and Charitable Choice, 13 NOTRE DAME J.L. ETHICS \& PUB. POL'Y 243, 247 (1999) (maintaining that neutrality theory is not neutral); Frank S. Ravitch, A Funny Thing Happened on the Way to Neutrality: Broad Principles, Formalism, and the Establishment Clause, 38 GA. L. REV. 489, 493 (2004) ("Claims of neutrality cannot be proven. There is no independent neutral truth or baseline to which they can be tethered."); Wright, supra note 237, at 905 (concluding that claims of neutrality are "incoherent" and there is no way to "reinterpret, rehabilitate, or otherwise rescue the idea of neutrality in the Religion Clause context").

259. See, e.g., Shiffrin, supra note 214, at 93 ("The Free Exercise Clause is supported by seven values: (1) it protects liberty and autonomy; (2) it avoids the cruelty of forcing an individual to do what he or she is conscientiously obliged not to do or to penalize an individual for responding to an obligation of conscience; (3) it preserves respect for law and minimizes violence triggered by religious conflict; (4) it combats religious discrimination; (5) it protects associational values; (6) it promotes political community; and (7) it protects the personal and social importance of religion." (footnotes omitted)).

260. Alan E. Brownstein, Justifying Free Exercise Rights, 1 U. ST. THOMAS L.J. 504, 548 (2003); William P. Marshall, Religion As Ideas: Religion As Identity, 7 J. CONTEMP. LEGAL 
reading, it is agnostic (pun intended) as to the value of religion. Indeed, it extends to non-religion the protections of the "religion" clauses. ${ }^{261} \mathrm{On}$ the other hand, some scholars argue that the modern focus on autonomy is misplaced. ${ }^{262}$ The focus on autonomy, along with its attendant secular virtues, ignores the real motivation for religious belief and practice.

Ultimately, current justifications of religious freedom fail because they do not take religion seriously on its own terms. No Muslim believes that he should make a pilgrimage to Mecca to raise the general level of civic virtue. He does it because his faith that there is no God but Allah and that Mohammed is his Prophet teaches that only by completing the hadj can he qualify for entry into paradise. Likewise, Orthodox Jews are not interested in creating mediating institutions but in faithfully fulfilling the conditions of the covenant God made with Moses and Israel on Mount Sinai. Buddhist temples are not factories for the production of social capital but places where people attempt to follow the example of Buddha to nirvana. Christian churches are not components of some philosophy of the "secular public realm" but meetings of "fellow citizens with the saints, and of the household of God" seeking salvation through Jesus Christ the Son of God. In short, the current arguments generally offered in favor of religious liberty have nothing to do with the ultimate concerns that are at the heart of religious belief. They simply do not take such concerns seriously. ${ }^{263}$

ISSUES 385, 406 (1996) (concluding that religion is a set of ideas and constitutive of personal identity); David B. Salmons, Toward a Fuller Understanding of Religious Exercise: Recognizing the Identity-Generative and Expressive Nature of Religious Devotion, 62 U. CHI. L. REV. 1243, 1258 (1995); Greene, Is Religion Special?, supra note 256, at 536-37. But see McClain, supra note 178 .

261. See Welsh v. United States, 398 U.S. 333, 340 (1970) (holding that purely ethical or moral beliefs that impose a duty of conscience qualify for religious exemption for military draft); United States v. Seeger, 380 U.S. 163, 165-66 (1965) (holding that "sincere and meaningful" belief that holds same place as conventional religious belief satisfies statutory requirement for conscientious objector status).

262. See, e.g., John H. Garvey, An Anti-Liberal Argument for Religious Freedom, 7 J. CONTEMP. LEGAL ISSUES 275, 280 (1996) (stating that autonomy cannot explain complexity of religious liberty law); David C. Williams \& Susan H. Williams, Volitionalism and Religious Liberty, 76 CORNELL L. REv. 769 (1991) (arguing that volitional assumptions limit proper reach of the Free Exercise Clause).

263. Note, Wagering on Religious Liberty, 116 HARV. L. REV. 946, 950-51 (2003) (footnotes omitted) (quoting Ephesians 2:19 (King James)). 
Under this reading, the Framers were not agnostic (in either sense) about the purpose of the Free Exercise Clause. They wanted to protect religion. ${ }^{264}$ As Michael Stokes Paulsen puts it:

The Free Exercise Clause only makes sense on the assumption that God exists; that God makes claims on the loyalty of human beings; and that these claims are prior to and superior in obligation to the claims of the State. The Clause thus embodies an essentially religious premise. ${ }^{265}$

The Framers intended to create legal equality among all religions and protect those actions that flowed from a religious premise ${ }^{266}$ To do otherwise renders the religion clauses incoherent because it ends up protecting purely secular behavior:

If the Free Exercise Clause ... confer[s] a sphere of immunity from facially neutral government regulation, then the "exercise" of atheism, agnosticism, skepticism, rationalism, humanism, and secularism indeed confers a huge area of exemption from government laws. And it is a zone of exemption having, really, nothing much to do with religion. It is secular freedomautonomy in general - treated as on par with religion, because it is religion's complement, secular analog, or even opposite. ${ }^{267}$

Members of each camp sometimes reach the same conclusion about how strong the Free Exercise Clause should be. ${ }^{268}$ Michael Stokes Paulsen puts the case thusly:

[W] protect religious liberty because religion is important - or, as I would refine it, because God exists and His claims are of

264. McConnell, Why Protect, supra note 211, at 777-81 (the Framers intended religious exemptions). But see Hamburger, supra note 216, at 932 (stating that there is little evidence the Framers intended broad religious exemptions).

265. Michael Stokes Paulsen, God Is Great, Garvey Is Good: Making Sense of Religious Freedom, 72 NOTRE DAME L. REV. 1597, 1598 (1997) [hereinafter Paulsen, God Is Great].

266. McConnell, Why Protect, supra note 211, at 777-81, 808.

267. Paulsen, God Is Great, supra note 265, at 1603.

268. Compare Paulsen, God Is Great, supra note 265, at 1610 ("Accordingly, the Free Exercise Clause confers an area of substantive immunity from government regulation that interferes with religious belief and exercise. We prefer the sincere individual's claim of religious conscience to the government's claim of secular authority, absent an extraordinary showing of insincere religion or of a threat to state interests of the highest order."), with Laycock, Religious Exemptions, supra note 69, at 176 ("Regulatory exemptions are an essential part of meaningful religious liberty. The right to believe a religion is hollow without the right to practice the religion; it leaves committed believers subject to persecution for exercising their religion."). 
prior and greater obligation than those of the state - we should protect only those religions whose beliefs and commands we understand to fall within the acceptable range of having a plausible claim to be True Beliefs. In fact, however, we protect much more, including a considerable amount of what even religious people view as religious rubbish. We do so because we do not trust political majorities, and we certainly do not trust government agents, to distinguish Truth from Rubbish and because it is exceedingly difficult (and dangerous) to try to draft a religious freedom rule that successfully draws such a line. In short, we protect the core freedom because we believe it consists of something objectively important and true, and we adopt an overbroad prophylactic rule for the sake of protecting the core freedom. At least, that was probably the original purpose of protecting religious freedom. ${ }^{269}$

These conceptual issues merge in weapons cases. Courts must decide whether or not a substantial burden on religion exists. To get there, they must resolve the background questions of the Free Exercise Clause's purpose and what should count as a "religious burden."270 That they do so silently and unwittingly speaks volumes about the incoherency of contemporary free exercise law.

269. Paulsen, God Is Great, supra note 265, at 1606.

270. This dilemma repeated itself in the litigation over the Affordable Care Act. Burwell v. Hobby Lobby Stores, Inc., 134 S. Ct. 2751 (2014) (holding that a mandate in the Affordable Care Act requiring private businesses to provide insurance coverage for contraception violated the Religious Freedom Restoration Acts because it forced them to facilitate activities that violated their religious beliefs without sufficient justification). Like the Georgia and Minnesota plaintiffs, the plaintiffs argued that simply complying with the law was a significant burden that could not be justified by any compelling government interest. Id. at 2764-67, 2780 (arguing that complying with law's minimum insurance requirements burdened plaintiff's religious beliefs). Resolving these cases in favor of the plaintiffs, the Court had to first accept - on faith, as it were - that religious beliefs and not personal preferences undergirded these claims. See id. at 2778-79; see also Hobby Lobby Stores, Inc. v. Sebelius, 723 F.3d 1114, 1141 (10th Cir. 2013) ("[W]hen the plaintiff drew a moral line between foundry and factory work, it was not the Court's prerogative to determine whether the line he drew 'was an unreasonable one."' (quoting Thomas v. Review Bd., 450 U.S. 707, 715 (1981)). The religious nature of these claims may seem self-evident, but that is precisely the way that "natural" religious claims are always privileged. Their claims are no more selfevident than either the Edina Lutherans or Georgia Baptists claims were. See GeorgiaCarry.org, Inc. v. Georgia, 687 F.3d 1244 (11th Cir. 2012); Edina Cmty. Lutheran Church v. State, 745 N.W.2d 194, 203-08 (Minn. Ct. App. 2008). Imagine another set of plaintiffs claiming a religious obligation to provide contraception. It is hard to picture courts so easily finding a burden in those cases. Like the GeorgiaCarry.org plaintiffs, their claims would not seem "natural." 
These seemingly minor cases reveal how muddy and opaque free exercise law is. ${ }^{271}$ Courts decide cases without a clear conceptual or historical framework. They silently measure the claim by the degree to which the claim seems compatible with their own experience, thus making free exercise law a reflection of their conceptions, fears, and assumptions about religion. It is, as it were, that courts only "see through a glass, darkly."272 We await the day when they can see directly.

271. Alan Brownstein, Why Conservatives, and Others, Have Trouble Supporting the Meaningful Enforcement of Free Exercise Rights, 33 HARV. J.L. \& PUB. POL'Y 925 (2010) (American free exercise jurisprudence is "shallow").

272. 1 Corinthians 13:12 (King James). Paul described how difficult it is for human beings to comprehend things that could not be directly grasped by our current experience which the King James version poetically and beautifully translated as "through a glass, darkly." Id. This notion is expressed more directly in some modern translations. See, e.g., 1 Corinthians 13:12 (New Living) ("Now we see things imperfectly as in a poor mirror."). Other translations are available at Compare Translations for 1 Corinthians 13:12, BIBLE STUDY TOOLS (last visited Mar. 27, 2015), http://www.biblestudytools.com/1-corinthians/1312-compare.html, archived at http://perma.cc/AH4V-236R. 